\title{
1 Control of lithospheric inheritance on neotectonic activity in
}

2 northwestern Canada?

3 Pascal Audet, Christian Sole, and Andrew J. Schaeffer

4 Department of Earth and Environmental Sciences, University of Ottawa, Ottawa, Canada, K1N

$5 \quad 6 N 5$

\section{ABSTRACT}

7 Lithospheric inheritance is thought to affect the location and reactivation of tectonic

8 structures through successive cycles of supercontinent formation and dispersal; however, its

9 relation to neotectonic activity remains unclear. In northwestern Canada, abundant seismicity

10 throughout the northern Canadian Cordillera (NCC) is geographically confined by several

11 crustal-scale boundaries, yet its southern extent terminates abruptly along the inferred westward

12 extension of a Late Cretaceous rifted margin boundary called the Liard Transfer Zone (LTZ). We

13 use seismic data to show that the uppermost mantle beneath the Cordillera exhibits a sharp north-

14 south contrast in fabric across the LTZ. South of the LTZ, fast axes of seismic wave propagation

15 align closely with the lithospheric mantle fabric orientation of the adjacent Canadian Shield.

16 North of the LTZ, fast axes reorient sub-parallel with the motion of the Pacific plate and follow

17 the strike of the large dextral strike-slip Tintina and Denali faults. We attribute changes in

18 anisotropic delay times across the Tintina and Denali faults to localized shear within the

19 lithosphere, which implies that the crust and lithospheric mantle remained mechanically coupled

20 during shearing. We propose that the contrast in uppermost mantle structure across the LTZ

21 reflects a change in the nature and origin of the lithospheric mantle from inherited rifted margin

22 structures, which affects the stability of the lithosphere and limits the extent of seismic activity 
23 within the NCC. These results indicate that neotectonic activity in modern Cordilleras is

24 controlled in part by inherited upper mantle structures.

\section{INTRODUCTION}

The Canadian Cordillera in western Canada is a wide, high-elevation, low relief orogenic

27 plateau that initially formed as a passive margin in Late Proterozoic-earliest Cambrian as the

28 result of the rifting of Laurentia, and underwent east-west compression in the Late Devonian

29 (Monger and Price, 2002). The northern Canadian Cordillera (NCC) is bounded to the west by

30 the Yakutat collision and the Alaskan border, to the east by the Proterozoic basement rocks of

31 the Canadian Shield, and to the north by the Beaufort Sea (Fig. 1A). Its southern extension is not

32 well defined but corresponds roughly with the southern limit of seismic activity, coinciding

33 approximately with the Yukon-BC border at latitude $60^{\circ}$ (Fig. 1A). This limit also follows the

34 westward extension of the Liard Transfer Zone (LTZ) inherited from the asymmetric rifted

35 margins of Laurentia that separated a lower plate (i.e., former foot wall) margin with seaward-

36 dipping blocks to the north from an upper plate (i.e., former hanging wall) margin characterized

37 by steep landward-dipping normal faults to the south (Cecile et al., 1997; Lund, 2008). The

38 westernmost crustal portion south of the LTZ moved northwestward due to strike-slip motion

39 along the Tintina Fault that produced approximately $450 \mathrm{~km}$ of right-lateral displacement

40 (Hayward, 2015).

41 The NCC currently exhibits a high rate of tectonic deformation, mainly along its western

42 portion around the Denali Fault and Yakutat collision zone, and across a broad zone to the north

43 and east in the Richardson and Mackenzie Mountains, approximately $800 \mathrm{~km}$ east of the plate

44 boundary (Fig. 1A; Leonard et al., 2008). The Tintina Fault generates only sparse, low

45 magnitude seismicity and is mostly inactive due to unfavorable contemporary stress conditions 
46 for strike-slip faulting (Maréchal et al., 2015). The current leading model to explain the high

47 seismicity and rate of deformation far from the plate boundary proposes a thin and rigid crustal

48 layer, decoupled from the underlying weak lower crust and mantle due to elevated basal

49 temperatures, which is pushed horizontally at the plate boundary to the west by the oblique

50 Yakutat collision and transmits stresses throughout the NCC (Mazzotti and Hyndman, 2002;

51 Hyndman et al., 2005). According to this model, the sub-lithospheric upper mantle beneath the

52 NCC is losing heat through vigorous and fluid-rich small-scale convection due to its recent

53 position in a back arc setting (Hyndman and Currie, 2011). This model is supported by low

54 values of effective elastic thickness (Audet et al., 2007) and high heat flow data across the NCC

55 (Lewis et al., 2003) that require a thin and weak lithospheric mantle $(\sim 30 \mathrm{~km})$ overlying a hot,

56 homogeneous and convecting sub-lithospheric mantle. It is unclear, however, which factors

57 control the geographical extent of seismicity within the Cordillera, in particular its southern

58 boundary, without detailed regional information on the structure and properties of the crust and

59 upper mantle.

60 UPPER MANTLE SEISMIC ANISOTROPY

61 Information on upper mantle structure can be obtained from estimates of seismic

62 anisotropy (i.e., the directional dependence of seismic wave propagation speed), which is related

63 to mineral fabrics that are generally acquired through shearing at high temperature via

64 dislocation creep mechanisms, and reflect either dynamic mantle flow processes, or fossilized

65 lithospheric fabric from past tectonic events (e.g., Long and Silver, 2009). Deciphering the

66 source of anisotropy can lead to a better understanding of the role of the crust and upper mantle

67 in controlling surface deformation. The source of upper mantle fabrics is generally attributed to

68 the strain-induced alignment of the abundant mineral olivine generally characterized by 
69 hexagonal symmetry (e.g., Nicolas and Christensen, 1987; Long and Silver, 2009). If the

70 alignment of anisotropic olivine minerals is coherent over some depth range, it gives rise to

71 observable seismic anisotropy. In particular, a singly polarized shear wave incident upon the

72 anisotropic medium will split into two orthogonally polarized shear waves travelling at different

73 wave speeds, a property commonly known as shear-wave splitting. Near-vertically propagating

74 core-refracted, radially polarized shear waves (primarily SKS waves) are particularly sensitive to

75 hexagonal anisotropy characterized by a horizontal axis of symmetry, enabling the study of

76 lateral mantle flow or fossilized fabric. The splitting of SKS waves is parameterized by the

77 accumulated delay time $(\delta t)$ between the fast and slow shear waves that vary as a function of the

78 intrinsic anisotropy and thickness of the anisotropic layer, and the azimuth $(\phi)$ of the fast axis of

79 shear wave propagation (i.e., S1 polarization direction).

80 We collected seismic data from 12 broadband stations across the NCC in the Yukon and

81 Northwest Territories, Canada, belonging to one of several seismic networks (Fig. 1B; Table

82 DR1). Seismic data were processed to estimate teleseismic shear-wave splitting parameters using

83 SKS phases (see Data Repository 201Xxxx). Single-station estimates were calculated from a

84 vector average, with mean uncertainties of approximately $10^{\circ}$ and $0.3 \mathrm{~s}$ for $\phi$ and $\delta t$, respectively.

85 We also compiled published shear-wave splitting data for all stations located in northwestern

86 Canada and southeastern Alaska. The final map of seismic anisotropy is shown in Figure 1B.

87 The most striking feature is the large-scale, coherent NE-SW alignment of fast axis directions

88 and large delay times $(>1 \mathrm{sec})$ observed in the Canadian Shield. This pattern has been previously

89 interpreted as a fossilized fabric within the thick $(>150 \mathrm{~km})$ lithospheric mantle of the North

90 American continent and/or the sub-lithospheric mantle flow direction from the absolute motion 
91 of the North American plate (Courtier et al. (2010); Snyder et al. (2007)) estimated from the

92 MORVEL-NNR model (DeMets et al., 2010).

93 Within the Cordillera, the alignment of fast axes varies over short spatial scales. Toward

94 the south and near the westward extension of the LTZ (Fig. 1B), fast axes are more closely

95 aligned with those observed in the Canadian Shield, and may be due to either or both the

96 extension of the North American fossilized fabric beneath the Cordillera, and the mantle flow

97 direction due to absolute plate motion of North America. These results point to a possible

98 influence of North American structure and/or dynamics on Cordilleran upper mantle fabric. To

99 the north of the LTZ, we observe a noticeable change in the alignment of seismic fast axes. The

100 northwestward, anti-clockwise rotation and margin-parallel alignment of the seismic fast axes

101 (Fig. 1B, blue bars) were separately interpreted as the increasing influence of the Pacific-North

102 America plate interactions $400 \mathrm{~km}$ from the plate boundary (Courtier et al., 2010), and fabric

103 from the deep transpressive shear zone of the Denali Fault (Rasendra et al., 2014), respectively.

104 The new data set (Fig. 1B, red bars) resolves a coherent alignment of seismic fast axes parallel to

105 both the strike direction of the Tintina Fault, $>200 \mathrm{~km}$ further away from the plate boundary, and

106 the absolute motion of the Pacific plate. The spatial pattern of seismic fast axes north of the

107 inferred LTZ suggests that upper mantle anisotropy may be related to sub-lithospheric mantle

108 flow beneath the NCC induced by Pacific plate motion, and/or fossilized fabric associated with

109 the two large crustal faults, which would require mantle penetrating shear zones.

\section{SHEAR ZONE FABRICS}

111 To investigate the influence of the Denali and Tintina faults on upper mantle anisotropy,

112 we extract splitting parameters along two profiles oriented perpendicular to the strike of the

113 Tintina Fault (Fig. 1B). Profile $X-X^{\prime}$ is located along the inferred extension of the LTZ, whereas 
114 profile $Y-Y^{\prime}$ is located $\sim 400 \mathrm{~km}$ to the northwest of the LTZ. The results are shown in Figure 2.

115 Along profile X-X', the azimuth of the seismic fast axes reflects a close alignment with the

116 fabric observed within the North American plate, and a consistent $\sim 30^{\circ}$ angle difference with the

117 absolute motion of North America (Fig. 2A). Azimuths rotate anti-clockwise toward the western

118 part of the profile (Fig. 1B, 2B), indicating a rotation of upper mantle fabric across a short

119 distance $(\sim 50 \mathrm{~km})$, as outlined previously. More significantly, the delay times decrease from 1

120 sec to almost no splitting within $100 \mathrm{~km}$ of the surface trace of the Tintina Fault (Fig. 2B). The

121 absence of splitting near the fault may suggest that it did not generate measurable large-scale

122 coherent strain in the upper mantle, which we find unlikely. Alternatively, we posit that the

123 decrease in delay times is caused by the erasure of pre-existing North American fossilized fabric

124 by prolonged orthogonal (NW-SE) shearing along the Tintina Fault, which may randomize or

125 reduce fabrics and produce no observable splitting. The role of the Tintina Fault in controlling

126 upper mantle fabric is supported by splitting estimates along profile $\mathrm{Y}-\mathrm{Y}^{\prime}$, where the azimuths

127 are well aligned with the strike of the two large crustal faults (Fig. 2C). More importantly, delay

128 times increase from $\sim 0.5 \mathrm{sec}$ to $>1.5 \mathrm{sec}$ over a similar distance of $100 \mathrm{~km}$ to both the Denali and

129 Tintina faults (Fig. 2D). Results from both profiles suggest that up to $0.75-1 \mathrm{sec}$ of accumulated

130 delay time may be due to fossilized fabric within the lithospheric mantle shear zones, with the

131 remainder possibly attributed to coherent, sub-lithospheric mantle flow. Assuming a negligible

132 contribution from crustal fabric, uniform shearing within a 30 to $50 \mathrm{~km}$ thick lithospheric mantle

133 with shear wave speed of $4.3 \mathrm{~km} / \mathrm{s}$ producing $0.75-1 \mathrm{sec}$ of anisotropic delay time amounts to 4 -

$13411 \%$ of shear-zone related anisotropy, similar to values observed along the Alpine Fault in New

135 Zealand (Zietlow et al., 2014) and other large transcurrent faults (Vauchez et al., 2012). 

through at least part of the Paleogene to Mid-Neogene, when $\sim 1000 \mathrm{~km}$ of dextral strike-slip

138 displacement was distributed across a network of faults, the largest of which (the Denali and

139 Tintina faults) accumulated $>400 \mathrm{~km}$ of dextral motion (Johnston, 2008; Rasendra et al., 2015).

140 North of the LTZ, the spatial coincidence of maximum anisotropic delay times with the surface

141 trace of the faults further suggest that the hypothesized lower crustal detachment (Mazzotti and

142 Hyndman, 2002) cannot have produced more than $\sim 20 \mathrm{~km}$ of fault-perpendicular displacement

143 of the upper crust relative to a weak lower crust and lithospheric mantle. This implies a

144 maximum rate of horizontal displacement of $\sim 1 \mathrm{~mm} \mathrm{yr}^{-1}$ through the Miocene consistent with

145 contemporaneous estimates from GPS data (Maréchal et al., 2015), but much lower than

146 previous estimates of $5 \mathrm{~mm} \mathrm{yr}^{-1}$ (Mazzotti and Hyndman, 2002). Finally, the bulk of seismic

147 anisotropy beneath the NCC appears to be related to fossil fabric from lithospheric mantle shear

148 zones, which leaves only a small possible contribution from coherent sub-lithospheric mantle

149 flow.

\section{INHERITANCE AND NEOTECTONICS}

151 The contrast in seismic anisotropy across the LTZ indicates a north-south step change in 152 the properties of the upper mantle in the Cordillera. One possible explanation for the change in 153 anisotropy is the thermally controlled glide in olivine that switches slip system at temperatures $154<1000^{\circ} \mathrm{C}$ (Durham and Goetze, 1977; see also Dumouchy et al., 2013). However, this low-

155 temperature transition is generally restricted to mylonites that accommodate the emplacement of 156 peridotite slices in the crust (Vauchez et al., 1998). Furthermore, upper mantle temperatures are 157 on average higher than $1000^{\circ} \mathrm{C}$ within the Cordilleran lithospheric mantle (Lewis et al., 2003).

158 Instead, we propose that the change in seismic anisotropy represents a lateral transition in the 
nature and origin of the lithospheric mantle fabric, which reflects a similar transition in the style

160 of rifting of the Late-Proterozoic Laurentian margin and coincides with a contrast in neotectonic

161 activity in the Cordillera (Fig. 3)

162 South of the LTZ, the preserved passive margin structures of the Cordillera are

163 characteristics of a former hanging wall margin formed by rifting on continent-ward dipping

164 listric normal faults (Fig. 3A,B). Seismic anisotropy results suggest that the inherited lithospheric 165 mantle of the former Laurentian margin underlies the Cordilleran crust south of the LTZ (Fig.

166 3C). North of the LTZ, the preserved passive margin structures of the NCC are characteristics of 167 a former foot wall margin with a broad sedimentary basin (Fig. 3A). In this region, the signature 168 of North American fossil fabric is absent, indicating that the upper mantle beneath the NCC has a 169 different origin. Instead, seismic anisotropy results indicate fabrics related to shearing along 170 mantle-penetrating shear zones. The nature of the upper mantle beneath the NCC is unclear and 171 could reflect material of a different origin (e.g., from terrane accretion), or the thermal erosion, 172 rejuvenation, or delamination of former North American lithospheric mantle (e.g., Bao et al., 173 2014), or else the tectonic and/or magmatic underplating beneath the NCC during convergence 174 and plateau uplift.

175 Current seismic activity throughout the NCC may be partly the result of the oblique

176 collision of the Yakutat block; however, the long-term crust-mantle coupling beneath the 177 transpressive faults within the NCC, as well as the low inferred displacement rate, suggest that 178 stress may be transmitted, at least in part, by a process complementary to the lower-crustal 179 detachment model (e.g., basal tractions; Finzel et al. (2015)). Regardless of the origin of 180 neotectonic activity, its lateral extent is confined by large-scale lithospheric boundaries. The 181 inferred preservation of North American lithospheric mantle beneath the Cordillera south of the 
182 LTZ suggests that the lithosphere remained relatively intact through plate convergence and 183 transpression since the Late Cretaceous that affected the entire Canadian Cordillera (Johnston,

184 2008). The long-term stability of the upper mantle lithosphere may provide a backstop for

185 neotectonic activity and control the extent of crustal deformation within the NCC. This

186 interpretation is consistent with the presence of large lower crustal mafic bodies that juxtapose

187 Cordilleran re-entrants (e.g., south of the LTZ), indicating a stronger lithosphere that forms

188 buttresses against active deformation (Saltus and Hudson, 2007). Finally, the olivine LPO fabric

189 may further induce large-scale mechanical anisotropy of the lithosphere, resulting in lateral

190 contrasts in the strength of the lithosphere in the contemporary stress field that concentrate

191 deformation perpendicular to the greatest strength directions (Audet and Bürgmann, 2011;

192 Vauchez et al., 1998).

193 ACKNOWLEDGMENTS

194 We thank A. Vauchez, S. Mazzotti and an anonymous reviewer for their insightful comments.

195 We also wish to thank the various federal, territorial and municipal agencies in the Yukon and

196 Northwest Territories (YT Highway and Public Works, YT Energy Mines and Resources, Town

197 of Faro, Town of Norman Wells, BC Wildfire Department, NT Environment and Natural

198 Resources, and Nav Canada) for allowing us access to their land in the installation of the Yukon-

199 Northwest Seismograph Network. This work is supported by the Natural Science and

200 Engineering Research Council (Canada) through a Discovery Grant to PA and a Postdoctoral

201 Fellowship to AJS, and by the Ministry of Research and Innovation of Ontario.

\section{REFERENCES CITED}

203 Audet, P., and Bürgmann, R., 2011, Dominant role of tectonic inheritance in supercontinent 204 cycles: Nat. Geo., v. 4, p. 184-187. 
Audet, P., Jellinek, A. M., and Uno, H., 2007, Mechanical controls on the deformation of continents at convergent margins: Earth Planet. Sci. Lett., v. 264, p. 151-166.

Bao, X., Eaton, D. W., and Guest, B., 2014, Plateau uplift in western Canada caused by lithospheric delamination along a craton edge: Nat. Geo., v. 7, p. 830-833.

Cecile, M. P., Morrow, D. W., and Williams, G. K., 1997, Early Paleozoic (Cambrian to Early Devonian) tectonic framework, Canadian Cordillera: Bull. Can. Petrol. Geol., v. 45, p. 5474.

Courtier, A. M., Gaherty, J. B., Revenaugh, J., Bostock, M. G., and Garnero, E. J., 2010, Seismic anisotropy associated with continental lithosphere accretion beneath the CANOE array, northwestern Canada: Geology, v. 38, p. 887-890.

DeMets, C., Gordon, R. G., and Argus, D. F., 2010, Geologically current plate motions: Geophys. J. Int., v. 181, p. 1-80, doi: 10.1111/j.1365-246X.2009.04491.x

Dumouchy, S., Tommasi, A., Ballaran, T. B., and Cordier, P., 2013, Low strength of Earth's uppermost mantle inferred from tri-axial deformation experiments on dry olivine crystals, Phys. Earth Planet. Int., v. 220, p. 37-49.

Durham, W. B., and Goetze, G., 1977, Plastic flow of oriented single crystals of olivine, 1. Mechanical data: J. Geophys. Res., v. 82, p. 5737-5753.

Finzel, E. S., Flesch, L. M., Ridgway, K. D., Holt, W. E., and Ghosh, A., 2015, Surface motions and intraplate continental deformation in Alaska driven by mantle flow: Geophys. Res. Lett., v. 42 , p. $4350-4358$.

Hayward, N., 2015, Geophysical investigation and reconstruction of lithospheric structure and its control on geology, structure and mineralization in the Cordillera of northern Canada and eastern Alaska: Tectonics, v. 34, p. 2165-2189. 
228 Hyndman, R. D., Flück, P., Mazzotti, S., Lewis, T. J., Ristau, J., and Leonard, L., 2005, Current

229 tectonics of the northern Canadian Cordillera: Can. J. Earth Sci., v. 42, p. 1117-1136.

230 Hyndman, R. D., and Currie, C.A., 2011, Why is the North America Cordillera high? Hot 231 backarcs, thermal isostasy, and mountain belts: Geology, v. 39, no. 8, p. 783-786.

232 Johnston, S. T., 2008, The Cordilleran ribbon continent of North America: Annu. Rev. Earth 233 Planet. Sci., v. 36, p. 495-530.

234 Leonard, J. L., Mazzotti, S., and Hyndman, R. D., 2008, Deformation rates estimated from 235 earthquakes in the northern Cordillera and eastern Alaska: J. Geophys. Res., v. 113, p. $236 \quad$ B08406.

237 Lewis, T. J., Hyndman, R. D., and Flück, P., 2003, Heat flow, heat generation, and crustal 238 temperatures in the northern Canadian Cordillera: Thermal control of tectonics: J. Geophys. 239 Res., v. 108, no. B6, 2316.

240 Long, M. D., and Silver, P. G., 2009, Shear wave splitting and mantle anisotropy: Measurements, 241 interpretations, and new directions: Surv. Geophys., v. 30, p. 407-461.

242 Lund, K., 2007, Geometry of the Neoproterozoic and Paleozoic rift margin of western Laurentia:

243 Implications for mineral deposit settings: Geosphere: v. 4, no. 2, p. 429-444.

244 Maréchal, A., Mazzotti, S., Elliott, J. L., Freymueller, J. T., and Schmidt, M., 2015, Indentor245 corner tectonics in the Yakutat-St. Elias collision constrained by GPS: J. Geophys. Res., v., $246 \quad$ 120, p. 3897-3908.

247 Mazzotti, S., \& Hyndman, R. D., 2002, Yakutat collision and strain transfer across the northern 248 Canadian Cordillera: Geology, v. 30, p. 495-498.

249 Monger, J., and Price, R., 2002, The Canadian Cordillera: Geology and tectonic evolution: 250 CSEG Recorder, v. 27, p. 17-36. 
251 Nicolas, A., and N. I. Christensen, 1987, Formation of anisotropy in upper mantle peridotites-a 252 review, in The Composition, Structure and Dynamics of the Lithosphere-Asthenosphere System, American Geophysical Union Geodynamics Series, edited by C. Froidevaux and K. $254 \quad$ Fuchs, pp. 111-123.

255 Rasendra, N., Bonnin, M. Mazzotti, S., and Tiberi, C., 2014, Crustal and upper-mantle 256 anisotropy related to fossilized transpression fabric along the Denali Fault, northern Canadian Cordillera: Bull. Seism. Soc. Am., v. 104, p. 1964-1975.

258 Saltus, R. W., and Hudson, T. L., 2007, Regional magnetic anomalies, crustal strength, and the 259 location of the northern Cordilleran fold-and-thrust belt: Geology, v. 35, no. 6, p. 567-570.

260 Snyder, D., and Bruneton, M., 2007, Seismic anisotropy of the Slave craton, NW Canada, from 261 joint interpretation of $S K S$ and Rayleigh waves: Geophys. J. Int., v. 169, p. 170-188.

262 Vauchez, A., Tommasi, A., and Barruol, G., 1998, Rheological heterogeneity, mechanical 263 anisotropy and deformation of the continental lithosphere: Tectonophysics, v. 296, p. 61-86

264 Vauchez, A., Tommasi, A., and Mainprice, D., 2012, Faults (shear zones) in the Earth's mantle: 265 Tectonophysics, v. 558-559, p. 1-27.

266 Zietlow, D. W., Sheehan, A. F., Molnar, P. H., Savage, M. K., Hirth, G., Collins, J. A., and 267 Hager, B. H., 2014, Upper mantle seismic anisotropy at a strike-slip boundary: South Island, 268 New Zealand: J. Geophys. Res., v. 119, p. 1020-1040.

270 FIGURE CAPTIONS

271 Figure 1. A. Map of northwestern Canada. Grey dots show earthquakes that occurred between 2722000 and 2016. Thick white lines indicate tectonic boundaries separating the northern Canadian 273 Cordillera (NCC) from the adjacent Canadian Shield (CS). AB: Alberta; AK: Alaska; BC: 
274 British Columbia; NT: Northwest Territories; NU: Nunavut; YK: Yukon. The Liard Transfer

275 Zone (Liard TZ) is shown as white dashed lines. B. Multi-event average results of teleseismic

276 shear-wave splitting. Blue and red bars with white symbols show the orientation of the seismic

277 fast axes and the accumulated delay time between the fast and slow shear waves for each station

278 in the compiled data set (blue) and from this study (red). Compiled data are from Courtier et al.,

279 (2010), Rasendra et al. (2014), and Snyder et al. (2007). Square and triangular symbols show

280 stations for which the splitting parameters are projected along lines $\mathrm{X}-\mathrm{X}^{\prime}$ and $\mathrm{Y}-\mathrm{Y}^{\prime}$, respectively,

281 and shown in Figure 2. Large white arrows with labels show the absolute plate motion directions

282 of North America (NA) and Pacific (PAC) plates, according to the no-net rotation frame model

283 of DeMets et al., 2010.

285 Figure 2. Multi-event station average $\phi(\mathbf{A}, \mathbf{C})$ and $\delta t(\mathbf{B}, \mathbf{D})$ along the $\mathrm{X}-\mathrm{X}^{\prime}(\mathbf{A}, \mathbf{B})$ and $\mathrm{Y}^{\prime} \mathrm{Y}^{\prime}(\mathbf{C}$, 286 D) profiles perpendicular to the Tintina Fault (dotted vertical line at distance of $0 \mathrm{~km}$ ) shown in

287 Figure 1B. Thick solid lines show the average absolute plate motion of the North American (NA) 288 and Pacific (PAC) plates from the MORVEL model (DeMets et al., 2010). The horizontal black 289 dashed line in $\mathbf{A}$ and $\mathbf{C}$ shows the strike of the Tintina Fault along both profiles.

291 Figure 3. A. Late Proterozoic-Early Cambrian rifted margin of Laurentia showing a south-to292 north transition from an upper plate margin to a lower plate margin along the Liard Transfer 293 Zone. B. Schematic style of faulting along the asymmetric rifted margin and across the LTZ. C.

294 Contemporary tectonic setting in northwestern Canada, showing the inferred location of North

295 American upper mantle underlying the Cordilleran crust south of the LTZ in relation with 296 neotectonic activity (shown by earthquakes). Figure modified from Lund (2008). 
$298{ }^{1}$ GSA Data Repository item 201Xxxx, describing the methodology for single-event teleseismic

299 SKS splitting, two figures with example results and two tables with compiled estimates, is

300 available online at www.geosociety.org/pubs/ft20XX.htm, or on request from

301 editing@geosociety.org or Documents Secretary, GSA, P.O. Box 9140, Boulder, CO 80301, 302 USA. 

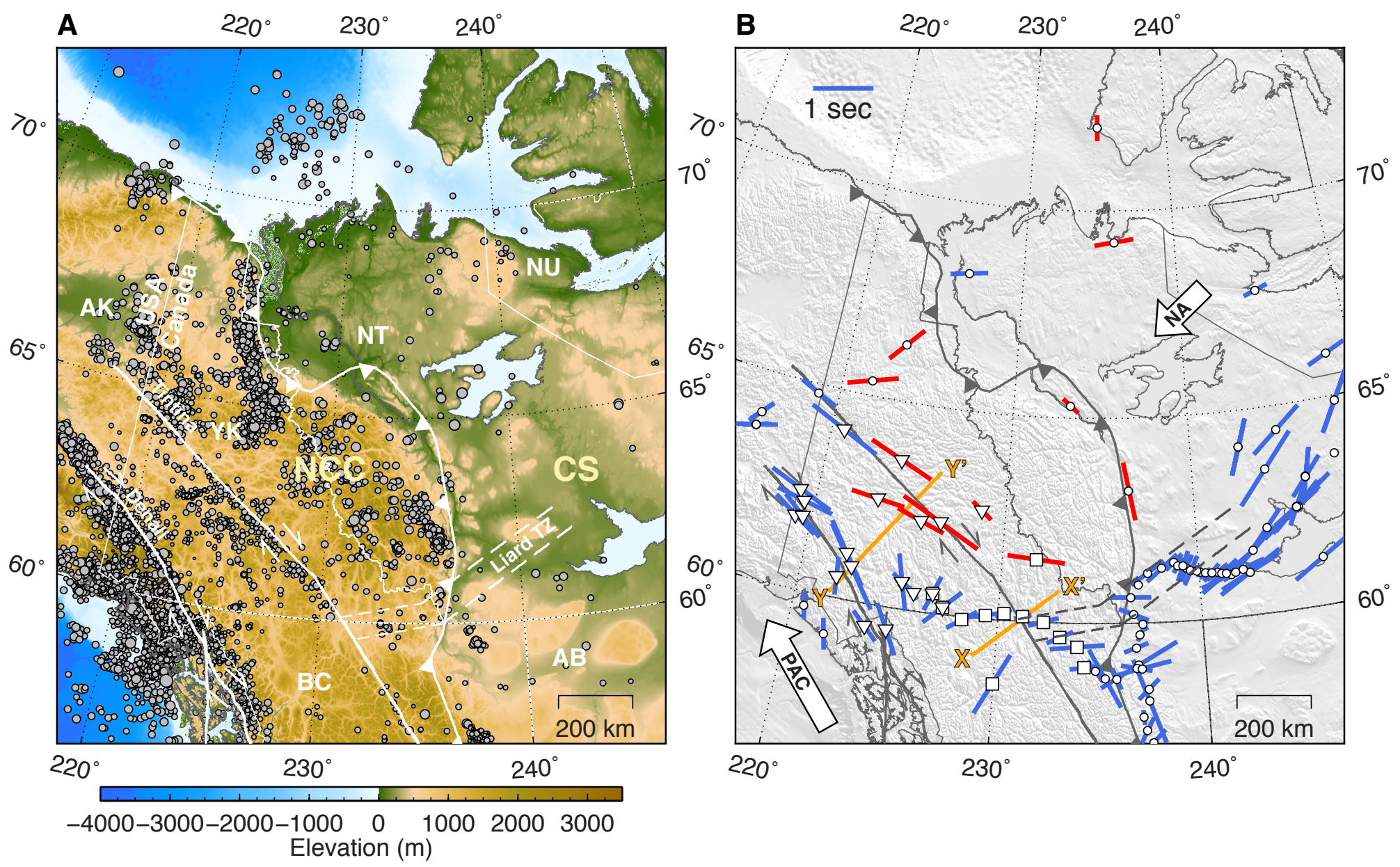

Figure 1 

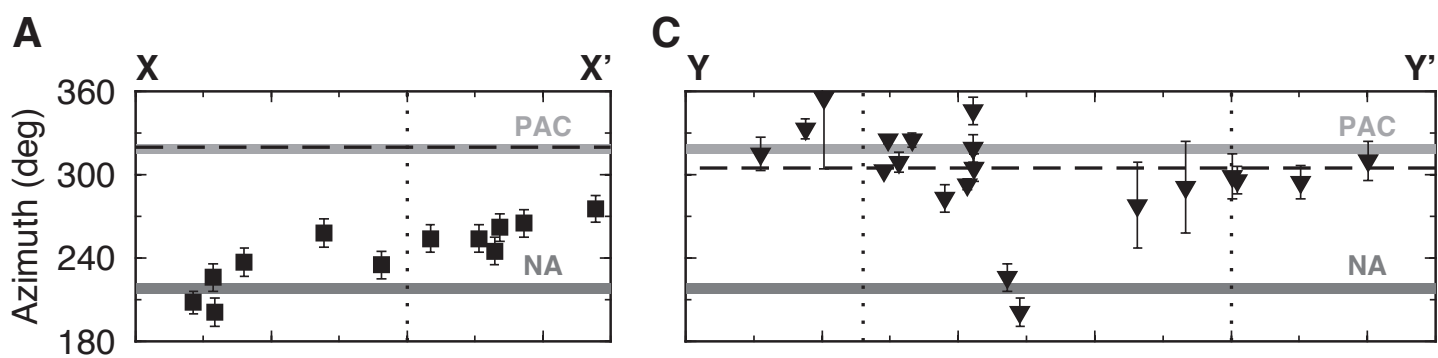

B

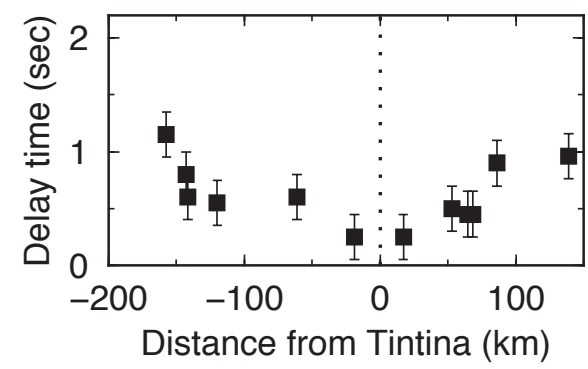

D

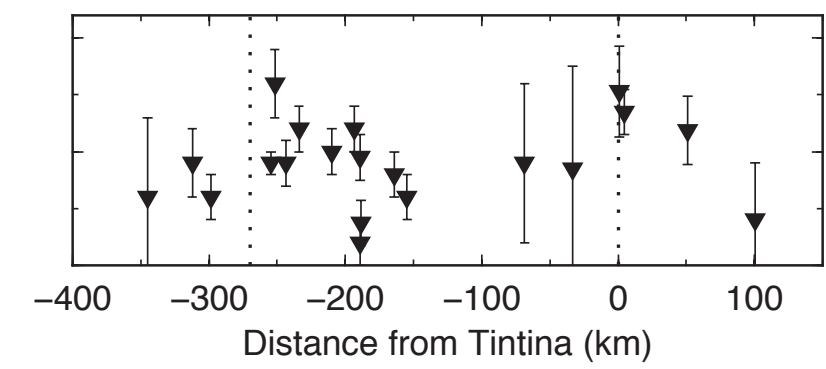

Figure 2 

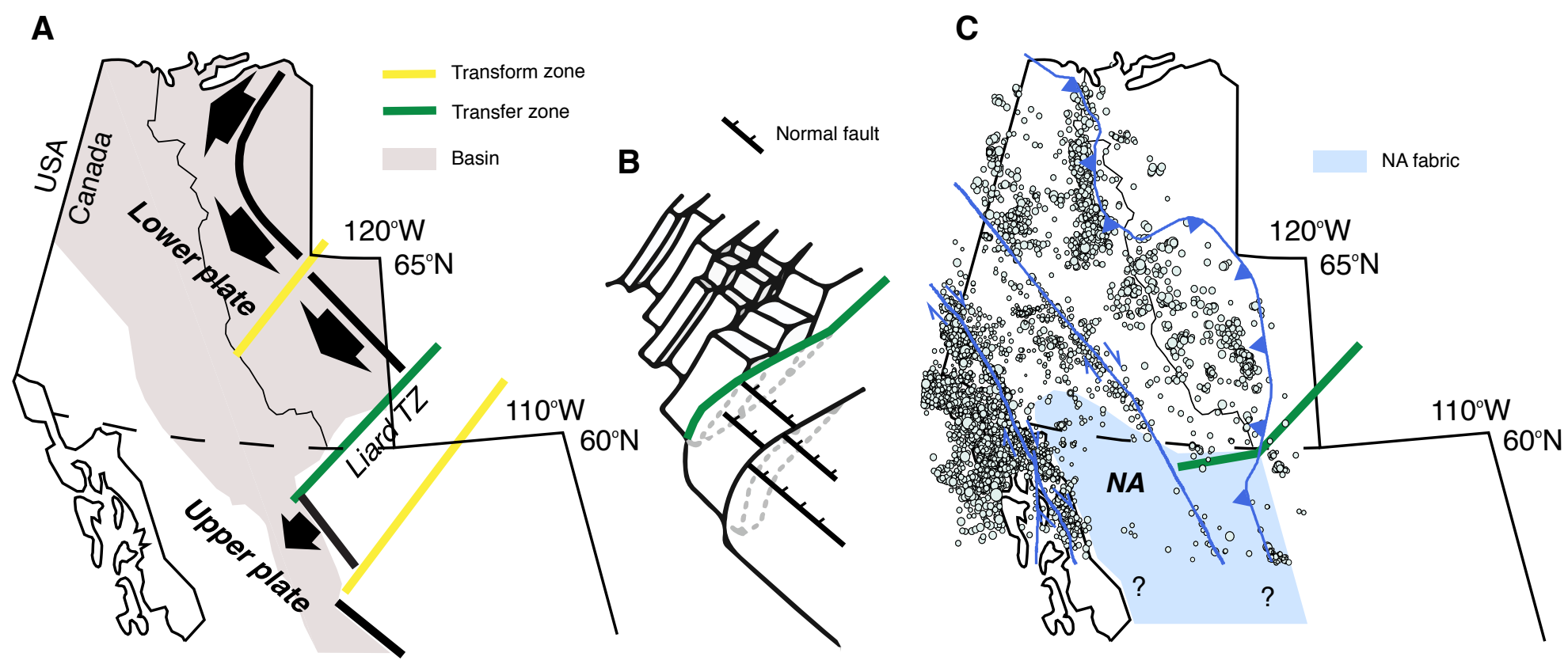

Figure 3 


\section{Control of lithospheric inheritance on neotectonic activity in}

3 northwestern Canada?

$4 \quad$ Pascal Audet, Christian Sole, and Andrew J. Schaeffer

5 Department of Earth and Environmental Sciences, University of Ottawa, Ottawa, Canada, K1N

$6 \quad 6 N 5$

8 TELESEISMIC SHEAR-WAVE SPLITTING ANALYSIS

9 Upon entering an anisotropic medium characterized by azimuthal anisotropy, upgoing radially-

10 polarized and planar SKS waves will split into two orthogonal components, one of which will

11 travel along the fast axis of seismic propagation (with azimuth $\phi$ ), whereas the other component

12 will travel along the perpendicular slow axis. Depending on the thickness of the medium and

13 wave speed difference between the fast and slow axis of hexagonal symmetry, a delay time $\delta t$

14 will accumulate between the two polarized shear waves. The splitting process is thus completely

15 characterized by the parameters $\phi$ and $\delta t$ (Silver, 1996). Incidentally, shear waves initially

16 travelling along one of the symmetry axes will not produce any observable splitting. These

17 results are called "null" measurements and can further help to constrain the orientation $\phi$.

18 Anisotropy that varies with depth or described by a different class of symmetry (or hexagonal

19 anisotropy with a dipping axis of symmetry) will give rise to more complicated patterns of

20 splitting.

21 We used 6 stations from the Transportable Array of USArray (TA), 5 stations from the

22 Yukon-Northwest Seismograph Network (NY), and one station from the Polaris Network (PO) 
23 (Table DR1). We selected waveforms for all magnitude $M>6.0$ events with signal-to-noise ratio

24 greater than $4 \mathrm{~dB}$ in the epicentral distance range of $85-140^{\circ}$ that occurred between April 2014

25 and March 2016. Waveforms are rotated into a longitudinal-radial-tangential (LQT) coordinate

26 system and filtered using a $0.05-0.15 \mathrm{~Hz}$ band-pass filter (Currie et al., 2004). Shear wave

27 splitting analysis at each station was carried out using the SplitLab software (Wüstefeld et al.,

28 2008) and resulted in 61 successful (i.e. non-null, see below) splitting measurements from SKS

29 phases (Tables DR1 and DR2). The number of estimates is low for recently installed stations of

30 the TA network. SplitLab performs the splitting analysis based on two distinct methods. The

31 energy minimization method (also called SC method) (Silver and Chan, 1991) seeks the splitting

32 parameters $\phi$ and $\delta t$ for which the energy of the transverse shear wave component is minimized

33 after inverting the splitting process. In contrast, the rotation-correlation method (also called the

34 RC method) rotates the seismogram of interest into a test coordinate frame and searches for the

35 pair of splitting parameters that gives the maximum cross correlation between the transverse and

36 radial SKS components (Wüstefeld et al., 2008).

37 Results are first classified into nulls if they satisfy two criteria: 1) SNR of the tangential

38 component of the SKS phase is below $3 \mathrm{~dB}$, or 2) the difference in $\phi$ obtained from the SC and

39 RC methods is between 22 and 68 degrees (Wüstefeld and Bokelmann, 2007). Both nulls and

40 non-nulls are then qualitatively evaluated in terms of "Good", "Fair" and "Poor" results based on

41 the ratio of RC and SC delay times $\left(\rho=\delta t_{\mathrm{RC}} / \delta t_{\mathrm{S}}\right)$ and the difference between RC and SC

42 azimuths $\left(\delta \phi=\max \left[\left|\phi_{\mathrm{RC}}-\phi_{\mathrm{SC}}\right|,\left|\phi_{\mathrm{SC}}-\phi_{\mathrm{RC}}\right|\right]\right)$ (Wüstefeld and Bokelmann, 2007). For Nulls, these

43 correspond to $\rho<0.2,37^{\circ}<\delta \phi<53^{\circ}$ for "Good" measurements; $\rho<0.3,32^{\circ}<\delta \phi<58^{\circ}$ for

44 "Fair"; and "Poor" otherwise. For non-Nulls, these correspond to $0.8<\rho<1.1, \delta \phi<8^{\circ}$ for 
45 "Good" measurements; $0.7<\rho<1.2, \delta \phi<15^{\circ}$ for "Fair"; and "Poor" otherwise. Parameter

46 uncertainty was estimated from the $95 \%$ confidence interval using an F-test (Walsh et al., 2013).

47 An example result of parameter estimation for a single event recorded at station EPYK is

48 shown in Figure DR1. Figure DR2 shows the compilation of "good" and "fair", non-null results

49 for station EPYK, sorted by back-azimuth of incoming SKS waves. These results show tightly

50 clustered estimates of both $\phi$ and $\delta t$, and we interpret these in terms of a single layer with

51 horizontal anisotropy. We note, however, that the event distribution is not uniform in back-

52 azimuth, and the single-layer assumption may not hold in reality. We then separately perform a

53 vector average of all "good" and "fair" non-null results (weighting the estimates equally) for both

54 the $\mathrm{SC}$ and $\mathrm{RC}$ techniques, and obtain final estimates by vector averaging the results of both

55 techniques into a single estimate of $\phi$ and $\delta t$ for each station (Table DR1), further preventing us

56 from considering more complex (i.e., multi-layered or dipping) anisotropy models. We also

57 ignore covariance and our error estimates are likely lower bounds. Figure DR3A shows all 'fair'

58 and 'good' measurements at each station.

59 Null estimates can also provide qualitative information on the robustness of the splitting

60 parameters. Null measurements occur because: 1) there is no detectable anisotropy beneath the

61 station; or 2) the incoming SKS wave propagates along either the slow or fast axis of anisotropy.

62 We plot the back-azimuth of all "good" null measurements as rose diagrams in Figure DR3B,

63 along with the estimated splitting parameters (reproduced from Figure 1B). Each set of

64 measurements is binned in $10^{\circ}$ back-azimuth and the length of the bars is proportional to the

65 percent number of measurements in each bin. These results show that the dominant back-

66 azimuths of "null" measurements are aligned with either the fast axis or perpendicular to it, thus

67 qualitatively confirming that the splitting measurements are robust. 
68 NOTES

69 The SplitLab software used in this study was translated from Matlab® to Python and thoroughly

70 tested against published results. The Python software makes extensive use of the ObsPy module

71 developed by Beyreuther et al. (2010), and is available upon request.

\section{REFERENCES CITED}

73 Beyreuther, R. Barsch, L. Krischer, T. Megies, Y. Behr and J. Wassermann, 2010, ObsPy: A

74 Python Toolbox for Seismology: Seism. Res. Lett., v. 81, no. 3, p. 530-533.

75 Currie, C. A., Cassidy, J. F., Hyndman, R. D., and Bostock, M. G., 2004, Shear wave anisotropy

76 beneath the Cascadia subduction zone and western North American Craton: Geophys. J. Int.,

$77 \quad$ v. 157, p. $341-353$.

78 Silver, P. G., 1996, Seismic anisotropy beneath the continents: Probing the depths of geology:

79 Annu. Rev. Earth Planet. Sci., v. 24, p. 385-432.

80 Silver, P. G., and Chan, W. W., 1991, Shear-wave splitting and subcontinental mantle

81 deformation: J. Geophys. Res., v. 96, p. 429-454.

82 Walsh, E., Arnold, R., and Savage, M. K., 2013, Silver and Chan revisited: J. Geophys. Res., v.

$83 \quad 118$, p. $5500-5515$.

84 Wüstefeld, A., and Bokelmann, G., 2007, Null detection in shear-wave splitting measurements:

85 Bull. Seism. Soc. Am., v. 97, no. 4, p. 1204-1211.

86 Wüstefeld, A., Bokelmann, G., Zaroli, C., and Barruol, G., SplitLab: A shear-wave splitting

87 environment in Matlab: Comp. Geosci.

88 


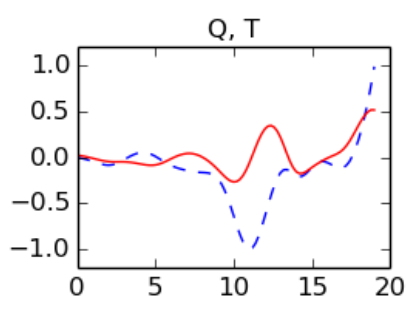

Event: Sun Jul 7 18:35:30 $2013 \quad-3.9234 \mathrm{~N}$ 153.9204E 386km Mw=7.3

Station: EPYK Backazimuth: 249.58 Distance: 85.43

Best fit RC values: $\phi=28 \pm 19.00 \delta t=1.0 \pm 0.45 \mathrm{~s}$

Best fit SC values: $\phi=32 \pm 19.00 \delta t=1.0 \pm 0.45 \mathrm{~s}$

Is Null? False Quality? Good
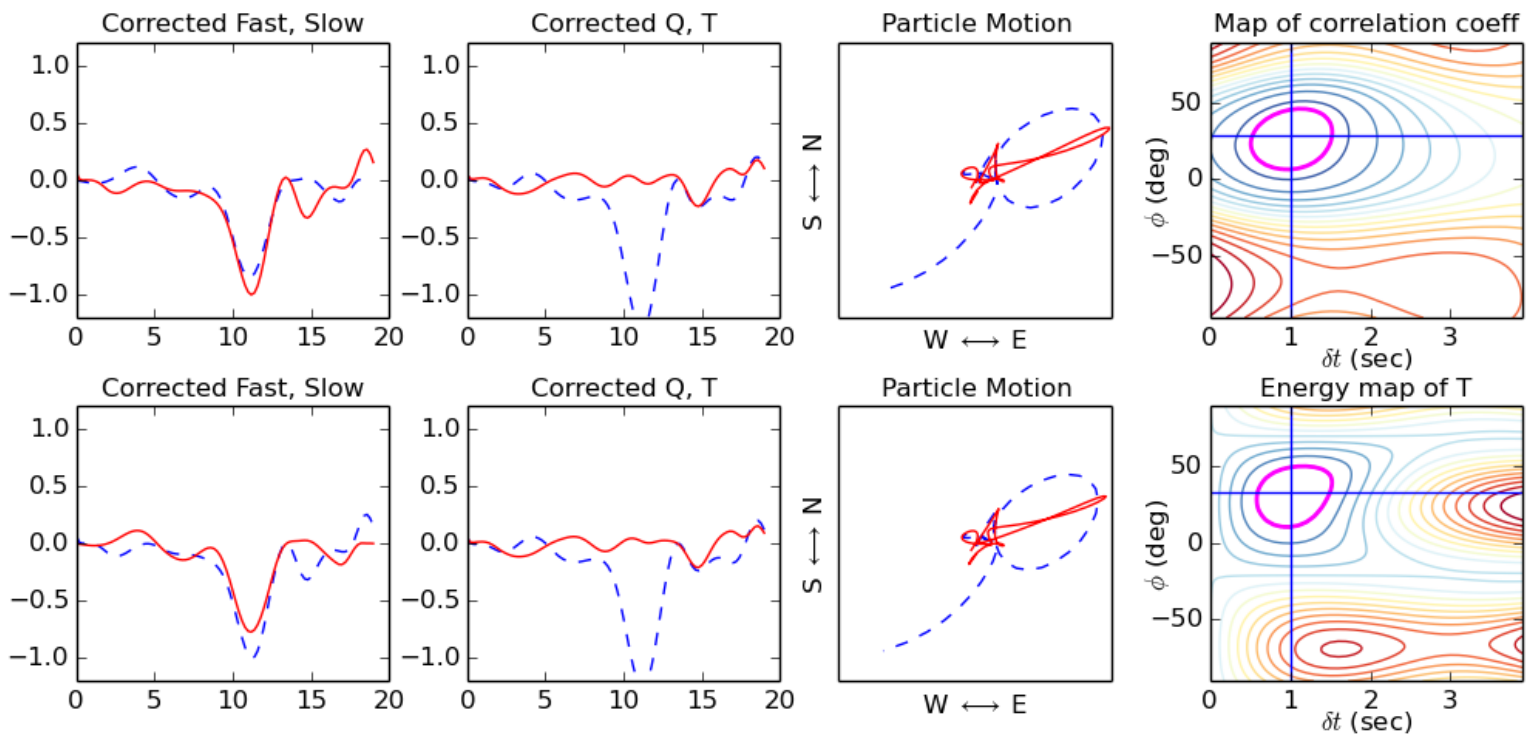

90 Figure DR1. Example result of a single-event estimate of SKS splitting obtained at station

91 EPYK. The text describes the earthquake parameters and best-fit estimates for both the RC and

92 SC techniques, as well as the quality factor. The top left panel shows the longitudinal (Q, blue)

93 and tangential ( $T$, red) seismograms for a hand picked window around the predicted SKS phase

94 arrival. The bottom two rows of panels show inversion results for the RC (middle row) and SC

95 (bottom row) techniques. For each technique, the first two panels represent the fast (blue) and

96 slow (red) components and the longitudinal (blue) and tangential (red) components after

97 removing the effect of splitting. Horizontal axis is time in seconds. The last two panels show the

98 initial (blue) and corrected (red) particle motion in the horizontal plane, and the misfit contours

99 (low misfit in blue, high misfit in red), shown either as a map of the correlation coefficient

100 between the corrected fast and slow components (RC) or the energy of the tangential component

101 after correction. The magenta contours show the 95\% confidence interval. 


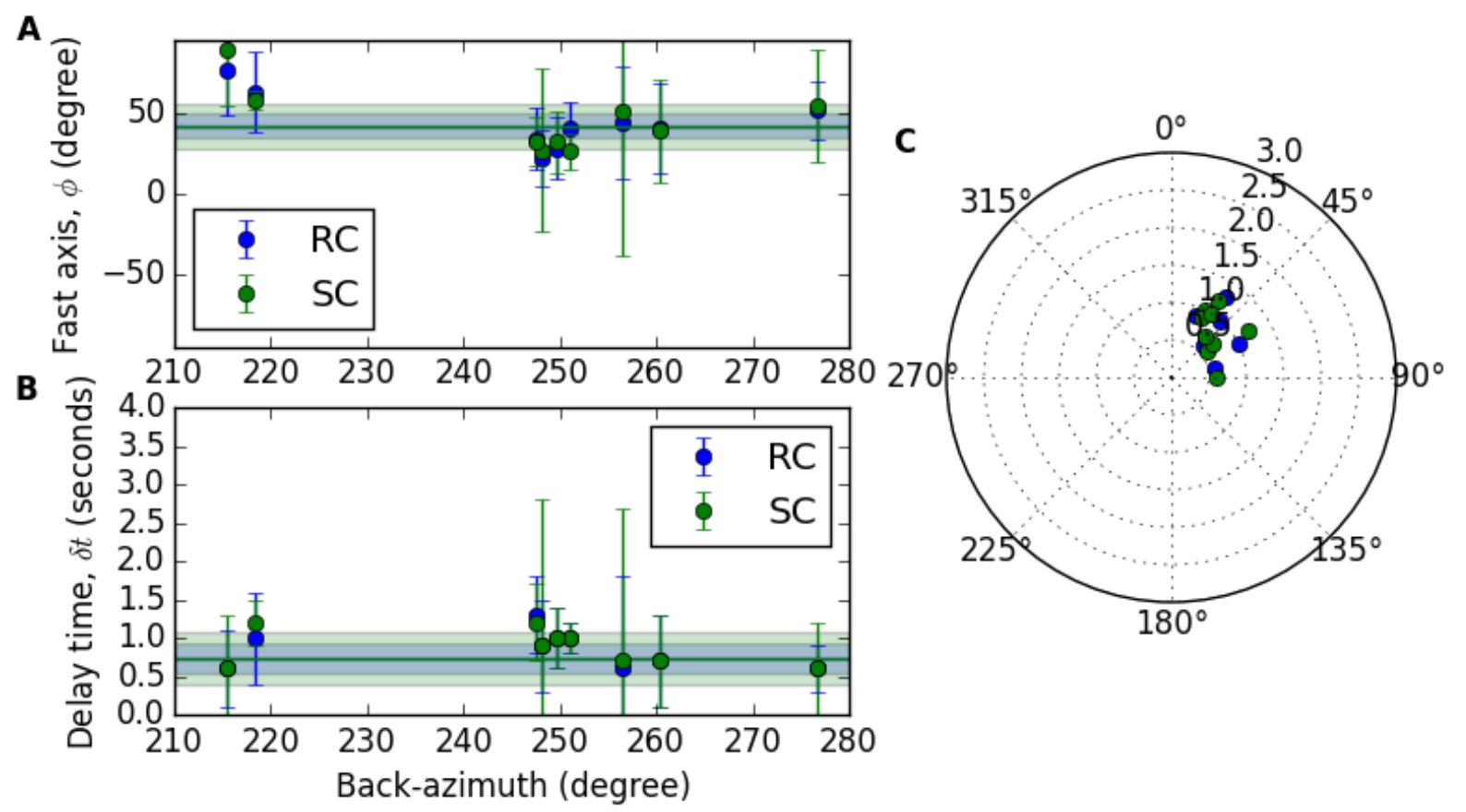

103 Figure DR2. Compilation of SKS splitting results for all "Good" and "Fair" non-nulls for station

104 EPYK. A: Azimuth of fast shear-wave propagation; B: Delay time between fast and slow shear

105 waves. Blue and Green symbols represent results obtained from the RC and SC techniques,

106 respectively. The blue and green shaded areas show the standard deviation of each quantity

107 around the mean value (solid lines) obtained from a vector average of individual measurements.

108 C: Representation of the estimated azimuths and delay times as a polar plot with delay time

109 increasing radially from the origin, which emphasizes the clustering of splitting parameters. 

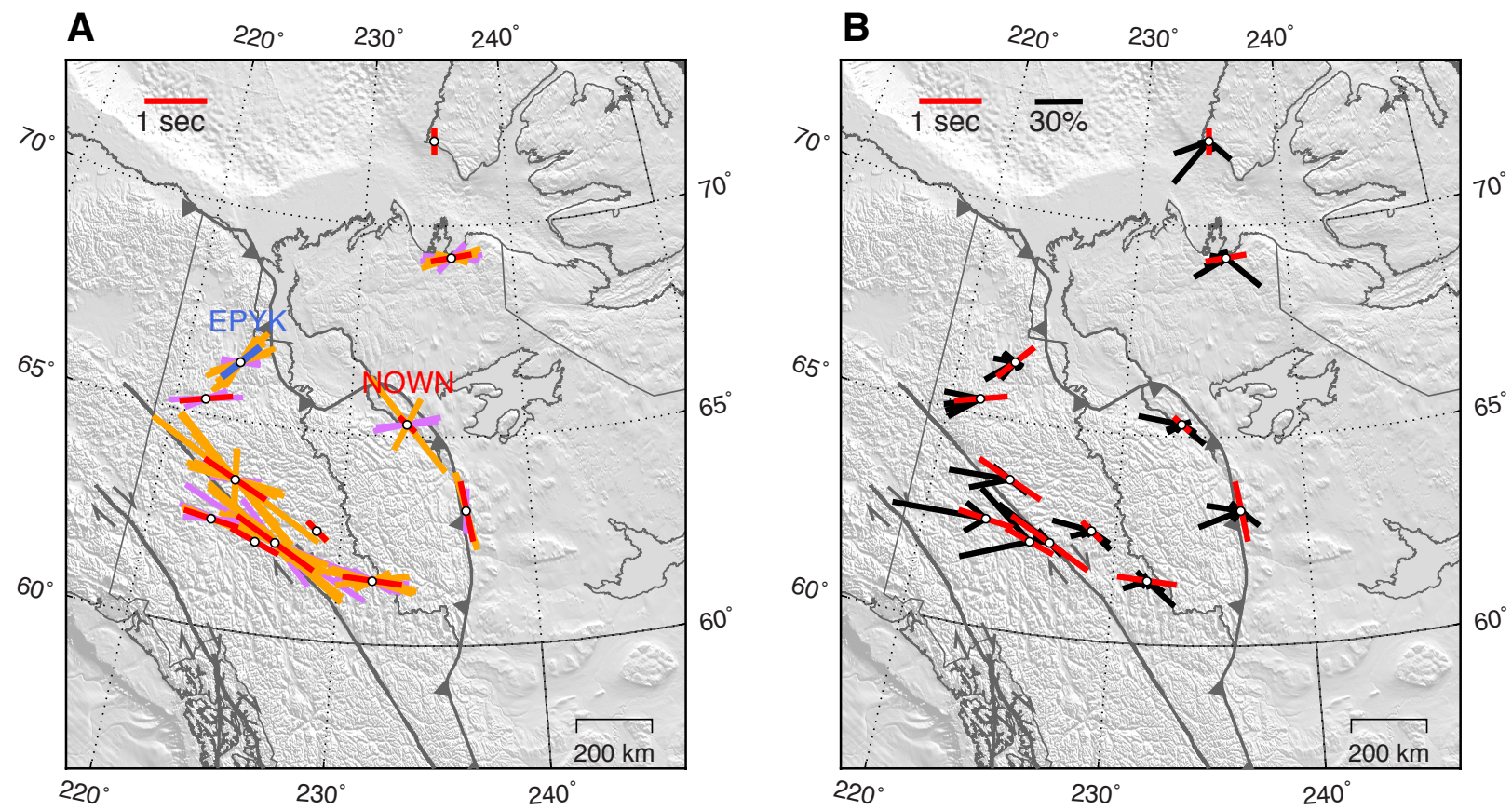

112 Figure DR3. A. Map of SKS splitting results for all "fair" and "good" non-nulls shown as purple

113 and orange bars, respectively. Except for station NOWN that displays variable fast axis

114 directions perhaps indicative of multi-layered anisotropy, all stations show a tight distribution

115 around the average parameters shown in red. Station EPYK is highlighted in blue. B. Map of null

116 measurements for all "good" nulls plotted as rose diagrams (black bars) of back-azimuths of

117 incoming SKS waves. The bars represent the percent number of events per $10^{\circ}$ back-azimuth bin.

118 Estimated SKS splits appear in red (reproduced from Figure 1B) in both A and $\mathbf{B}$. 


\begin{tabular}{|c|c|c|c|c|c|c|c|c|c|c|c|c|c|}
\hline \multirow{4}{*}{ 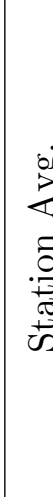 } & $\begin{array}{l}\overrightarrow{0} \\
0\end{array}$ & & 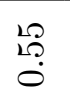 & $\begin{array}{l}\stackrel{+}{0} \\
0\end{array}$ & @̊ & $\stackrel{?}{\stackrel{0}{0}}$ & $\begin{array}{l}\infty \\
\stackrel{\infty}{0} \\
0\end{array}$ & $\stackrel{29}{\stackrel{2}{0}}$ & $\stackrel{N}{\stackrel{N}{0}}$ & $\stackrel{\sharp}{\sharp}$ & $\stackrel{\circ}{\dddot{\rho}}$ & 今ั & ָ̃ \\
\hline & $\begin{array}{l}\text { an } \\
\vec{t}\end{array}$ & $\begin{array}{l}\stackrel{10}{\infty} \\
\infty \\
0\end{array}$ & $\stackrel{?}{\circ}$ & 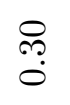 & 葛 & $\stackrel{?}{!}$ & :ִ & $\begin{array}{l}\infty \\
\stackrel{\infty}{0} \\
0\end{array}$ & $\stackrel{8}{\circ}$ & 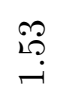 & $\stackrel{\overbrace{}}{\rightleftarrows}$ & & $\begin{array}{l}\mathscr{8} \\
\stackrel{0}{0}\end{array}$ \\
\hline & $\theta$ & $\begin{array}{l}\stackrel{8}{\infty} \\
\stackrel{\leftrightarrow}{\leftrightarrow}\end{array}$ & $\begin{array}{l}\stackrel{8}{\infty} \\
\stackrel{\dot{\rho}}{\text { N }}\end{array}$ & 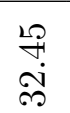 & & 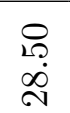 & $\stackrel{\stackrel{P}{+}}{\underset{\sim}{+}}$ & 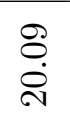 & 年 & $\begin{array}{l}\ddot{\infty} \\
\stackrel{0}{0}\end{array}$ & $\begin{array}{l}\stackrel{\infty}{\mathscr{D}} \\
\stackrel{\leftrightarrow}{\lrcorner}\end{array}$ & & $\begin{array}{l}\infty \\
\infty \\
\infty\end{array}$ \\
\hline & $\frac{\partial}{\theta}$ & $\begin{array}{l}8 \\
\stackrel{0}{0} \\
0\end{array}$ & $\begin{array}{l}8 \\
\stackrel{1}{0} \\
0.9\end{array}$ & 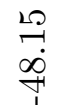 & 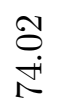 & 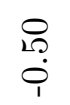 & $\begin{array}{l}\infty \\
\stackrel{\infty}{\infty} \\
\infty\end{array}$ & 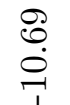 & $\begin{array}{l}\vec{N} \\
\underset{1}{0} \\
0\end{array}$ & $\begin{array}{l}\vec{N} \\
\stackrel{\oplus}{0}\end{array}$ & 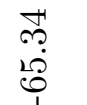 & 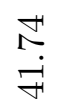 & $\begin{array}{l}\vec{b} \\
\dot{+} \\
0\end{array}$ \\
\hline & \# & $\neg$ & - & $\infty$ & $N$ & - & $\wedge$ & N & N & $\sigma$ & $\underset{\sim}{\sim}$ & & $\stackrel{ }{-}$ \\
\hline & $\overrightarrow{0}$ & 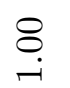 & $\stackrel{8}{\circ}$ & $\stackrel{\substack{P \\
0}}{0}$ & 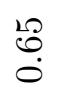 & $\stackrel{8}{\circ}$ & î̉ & 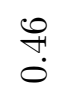 & $\underset{0}{\vec{H}}$ & $\stackrel{F}{F}$ & 点 & & ণ़ \\
\hline & an & $\stackrel{8}{\circ}$ & $\stackrel{?}{\stackrel{9}{0}}$ & 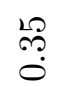 & 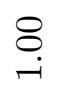 & $\stackrel{?}{\text { ? }}$ & $\stackrel{80}{0}$ & $\mathscr{8}$ & $\vec{\sigma}$ & : & $\stackrel{\overbrace{}}{\stackrel{9}{\rightarrow}}$ & & $\begin{array}{l}\infty \\
\stackrel{2}{0} \\
0\end{array}$ \\
\hline & $\theta$ & 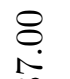 & $\stackrel{8}{\circ}$ & $\underset{\sim}{\stackrel{D}{~}}$ & $?$ & $\underset{\infty}{\stackrel{\infty}{0}}$ & 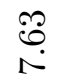 & $\stackrel{\vec{b}}{0}$ & 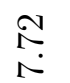 & 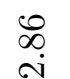 & 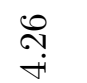 & & $\stackrel{R}{R}$ \\
\hline & & 凤 & ஜ & 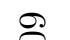 & 0 & & & & 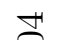 & 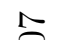 & & & 0 \\
\hline & $\theta$ & ن্ৰ: & 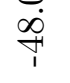 & 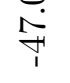 & $\stackrel{\substack{0 \\
i}}{\infty}$ & $\stackrel{\circ}{\rightarrow}$ & $\underset{\infty}{0}$ & $\vec{c}$ & $\underset{\substack{\infty \\
\infty}}{\substack{0 \\
1}}$ & م. & ثं & & 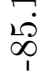 \\
\hline \multirow{4}{*}{ ح1 } & 范 & $\begin{array}{c}\stackrel{\infty}{\infty} \\
\stackrel{0}{0}\end{array}$ & ণิ & $\begin{array}{l}\mathscr{P} \\
0 \\
0\end{array}$ & 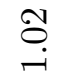 & ণ্ & $\stackrel{20}{\stackrel{2}{0}}$ & $\stackrel{\Re}{\stackrel{9}{0}}$ & 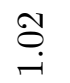 & $\stackrel{\infty}{\stackrel{0}{0}}$ & $\stackrel{\mathscr{L}}{\stackrel{9}{0}}$ & ণั & $\stackrel{0}{\circ}$ \\
\hline & $\begin{array}{l}\text { (a) } \\
\vec{t}\end{array}$ & $\begin{array}{l}\infty \\
\infty \\
0\end{array}$ & $\stackrel{\circ}{\stackrel{9}{0}}$ & 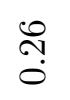 & $\underset{0}{0}$ & $\stackrel{\stackrel{\leftrightarrow}{0}}{\circ}$ & $\overrightarrow{0}$ & $\stackrel{8}{\stackrel{8}{-}}$ & $\stackrel{8}{\circ}$ & $\stackrel{\mathscr{I}}{-}$ & $\stackrel{109}{\rightarrow-}$ & $\stackrel{\mathbb{N}}{\stackrel{N}{0}}$ & $\begin{array}{l}28 \\
0 \\
0\end{array}$ \\
\hline & $0^{\theta}$ & $\underset{0}{8}$ & $\underset{10}{8}$ & 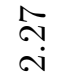 & $\mathfrak{T}$ & $\stackrel{8}{\circ}$ & $\stackrel{\leftrightarrow}{\leftrightarrow}$ & $\stackrel{\vec{N}}{\stackrel{3}{\sigma}}$ & $\vec{\sim}$ & 岕 & 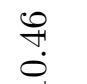 & & \begin{tabular}{c}
$\mathscr{\infty}$ \\
$\mathscr{0}$ \\
\hdashline \\
0
\end{tabular} \\
\hline & o & $\underset{\stackrel{+}{\perp}}{8}$ & $\begin{array}{l}8 \\
\text { ì }\end{array}$ & $\begin{array}{l}\vec{ন} \\
\stackrel{+}{+}\end{array}$ & $\begin{array}{l}10 \\
\infty \\
0 \\
0\end{array}$ & $\stackrel{8}{0}$ & $\begin{array}{l}\stackrel{ }{\wedge} \\
\infty\end{array}$ & $\begin{array}{l}\stackrel{2}{9} \\
\stackrel{9}{\rightarrow}\end{array}$ & 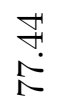 & 范 & $\begin{array}{l}\text { Fै } \\
\text { ¿̊ }\end{array}$ & $\stackrel{\mathscr{\leftrightarrow}}{\rightleftarrows}$ & $\begin{array}{l}28 \\
+ \\
+\infty\end{array}$ \\
\hline \multirow{6}{*}{ 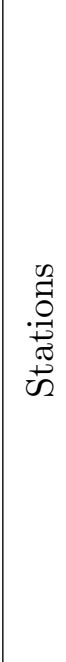 } & o & $\approx$ & 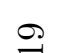 & $\nexists$ & $F$ & 0 & 工 & $\infty$ & 0 & 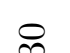 & 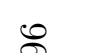 & 0 & \\
\hline & 苟 & ชี & ชิ่ & 8 & 8 & $\stackrel{\leftrightarrow}{i}$ & 8 & $\ddot{0}$ & तु & ชี & $\ddot{0}$ & $\dot{\theta}$ & பं \\
\hline & ¿ & $\vec{\sigma}$ & ॄֶ. & 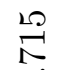 & \&્م & 品 & ? & $\begin{array}{l}\infty \\
\stackrel{\infty}{2} \\
\stackrel{7}{7}\end{array}$ & $\stackrel{\mathscr{\rho}}{\circ}$ & 市 & $\mathscr{\mathscr { D }}$ & & $\stackrel{\sim}{\stackrel{P}{N}}$ \\
\hline & & $\stackrel{\overrightarrow{9}}{\rightarrow}$ & $\stackrel{\overrightarrow{9}}{\rightarrow}$ & $\stackrel{\mathscr{\leftrightarrow}}{\stackrel{1}{1}}$ & $\begin{array}{l}\infty \\
\stackrel{0}{\rightarrow} \\
\rightarrow\end{array}$ & $\stackrel{201}{7}$ & $\underset{\mathrm{I}}{\stackrel{\overbrace{}}{7}}$ & 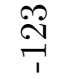 & $\stackrel{\mathscr{\Omega}}{\stackrel{9}{1}}$ & 笽 & 紫 & & 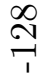 \\
\hline & 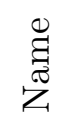 & 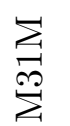 & 育 & 垈 & 急 & 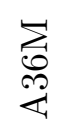 & $\begin{array}{l}\sum_{0} \\
\stackrel{\leftrightarrow}{0}\end{array}$ & 莺 & 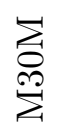 & 胥 & 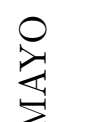 & & 忘 \\
\hline & 产 & $\overleftrightarrow{E}$ & 公 & $\stackrel{\circ}{2}$ & & $\overleftrightarrow{\sharp}$ & $\overleftrightarrow{\boxminus}$ & 枀 & $\overleftrightarrow{H}$ & 究 & 穵 & & 文 \\
\hline
\end{tabular}




\begin{tabular}{|c|c|c|c|c|c|c|c|c|c|c|c|c|c|c|c|c|c|c|c|}
\hline \multirow{4}{*}{ U } & $\overrightarrow{0}$ & $\stackrel{8}{\stackrel{0}{0}}$ & 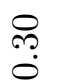 & $\begin{array}{l}\infty \\
\infty \\
0\end{array}$ & $\begin{array}{l}0 \\
0 \\
0\end{array}$ & \&! & $\underset{\sim}{\stackrel{8}{\&}}$ & $\stackrel{8}{\circledR}$ & $\underset{-}{8}$ & 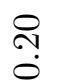 & $\underset{-}{\stackrel{9}{9}}$ & $\begin{array}{l}\stackrel{\ominus}{0} \\
\dot{0}\end{array}$ & $\stackrel{\leftrightarrow}{0}$ & 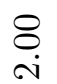 & مُ & $\stackrel{R}{?}$ & $\stackrel{?}{\stackrel{0}{0}}$ & $\begin{array}{l}0 \\
\dot{0}\end{array}$ & $\underset{\text { \& }}{\stackrel{8}{ }}$ \\
\hline & $\underbrace{\sqrt{n}}_{\infty}$ & $\stackrel{\circ}{\stackrel{0}{\circ}}$ & $\underset{-}{\stackrel{\overbrace{}}{\&}}$ & & $\begin{array}{l}\infty \\
\stackrel{\infty}{0}\end{array}$ & $\begin{array}{l}\stackrel{\ominus}{\bullet} \\
\dot{0}\end{array}$ & :? & $\begin{array}{l}\stackrel{0}{0} \\
\dot{0}\end{array}$ & $\stackrel{R}{R}$ & 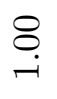 & $\stackrel{8}{\circ}$ & $\begin{array}{l}\stackrel{0}{0} \\
\dot{0}\end{array}$ & $\underset{\stackrel{\overbrace{}}{\sim}}{\stackrel{\overbrace{}}{*}}$ & $\stackrel{R}{0}$ & 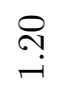 & $\begin{array}{l}\stackrel{8}{0} \\
\dot{0}\end{array}$ & $\underset{-}{\stackrel{8}{\&}}$ & $\stackrel{?}{\mathfrak{0}}$ & $\stackrel{?}{\stackrel{\leftrightarrow}{0}}$ \\
\hline & $\theta^{\theta}$ & $\begin{array}{l}8 \\
\infty \\
\infty \\
\infty\end{array}$ & $\stackrel{8}{\stackrel{0}{0}}$ & $\begin{array}{l}\text { \& } \\
\text { } \\
\text { i }\end{array}$ & $\begin{array}{l}\stackrel{8}{ } \\
\infty \\
\stackrel{\sim}{N}\end{array}$ & $\begin{array}{l}\& \\
\underset{f}{+}\end{array}$ & $\begin{array}{l}\& \\
\dot{\infty}\end{array}$ & $\begin{array}{l}8 \\
\stackrel{+}{+}\end{array}$ & $\begin{array}{l}\mathscr{8} \\
\dot{\infty} \\
\dot{\beta}\end{array}$ & $\begin{array}{l}\stackrel{8}{ } \\
\check{\beth}\end{array}$ & $\frac{8}{\text { ¿ }}$ & 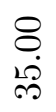 & $\begin{array}{l}8 \\
\dot{0}\end{array}$ & $\begin{array}{l}\mathscr{8} \\
\stackrel{\infty}{\infty}\end{array}$ & $\begin{array}{l}8 \\
10 \\
10\end{array}$ & $\begin{array}{l}8 \\
10 \\
10\end{array}$ & $\begin{array}{l}\stackrel{\odot}{ } \\
\stackrel{\infty}{\sim}\end{array}$ & $\begin{array}{l}8 \\
\text { هi } \\
\text { in }\end{array}$ & $\begin{array}{l}\stackrel{8}{\circ} \\
\dot{\infty}\end{array}$ \\
\hline & $\overbrace{\theta}^{\stackrel{o}{e}}$ & 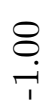 & $\begin{array}{l}8 \\
\stackrel{8}{1} \\
\text { i }\end{array}$ & $\begin{array}{l}8 \\
\stackrel{8}{\infty} \\
\infty\end{array}$ & $\begin{array}{l}8 \\
\dot{\infty} \\
\dot{\infty}\end{array}$ & $\begin{array}{l}8 \\
\stackrel{8}{+}\end{array}$ & $\begin{array}{l}8 \\
8 \\
10 \\
1 \\
1\end{array}$ & 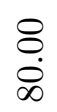 & $\begin{array}{l}8 \\
\infty \\
\infty \\
1\end{array}$ & $\begin{array}{l}\stackrel{8}{\odot} \\
\stackrel{0}{\circ}\end{array}$ & $\begin{array}{l}\stackrel{8}{8} \\
\text { N̦ }\end{array}$ & 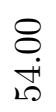 & $\begin{array}{l}\stackrel{8}{8} \\
\infty \\
\infty \\
10\end{array}$ & 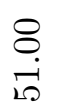 & $\begin{array}{l}\stackrel{8}{\Xi} \\
\text { ஸิ }\end{array}$ & $\begin{array}{l}8 \\
\stackrel{8}{\infty} \\
\infty\end{array}$ & $\begin{array}{l}\stackrel{8}{8} \\
\text { ஸे }\end{array}$ & $\begin{array}{l}\stackrel{8}{8} \\
\stackrel{\text { j}}{ }\end{array}$ & $\begin{array}{l}8 \\
\stackrel{0}{0} \\
\stackrel{0}{0}\end{array}$ \\
\hline \multirow{4}{*}{$\underset{\sim}{U}$} & $\overrightarrow{0}$ & 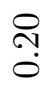 & $\stackrel{?}{\stackrel{0}{0}}$ & $\stackrel{?}{\stackrel{0}{0}}$ & $\stackrel{\circ}{\stackrel{\circ}{0}}$ & $\stackrel{\leftrightarrow}{\leftrightarrow}$ & $\stackrel{?}{\stackrel{R}{0}}$ & 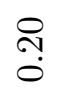 & 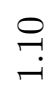 & ֻ̊ণ & $\begin{array}{l}\stackrel{\odot}{\bullet} \\
\dot{0}\end{array}$ & $\stackrel{\leftrightarrow}{\circ}$ & $\begin{array}{l}\stackrel{8}{\bullet} \\
\stackrel{0}{0}\end{array}$ & $\stackrel{\text { ণิ }}{\sim}$ & $\begin{array}{l}0 \\
\stackrel{1}{0} \\
0\end{array}$ & $\begin{array}{l}0 \\
\stackrel{1}{0} \\
0\end{array}$ & $\stackrel{?}{\stackrel{\leftrightarrow}{0}}$ & $\begin{array}{l}\stackrel{8}{0} \\
\dot{0}\end{array}$ & 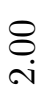 \\
\hline & $\underbrace{(\pi)}_{\sqrt{0}}$ & $\stackrel{\circ}{\stackrel{\leftrightarrow}{0}}$ & $\stackrel{8}{\circ}$ & $\stackrel{8}{\circ}$ & $\begin{array}{l}\infty \\
\stackrel{\infty}{0}\end{array}$ & $\begin{array}{l}0 \\
\stackrel{1}{10} \\
0\end{array}$ & $\begin{array}{l}0 \\
\stackrel{1}{0} \\
0\end{array}$ & $\begin{array}{l}\stackrel{0}{0} \\
\dot{0}\end{array}$ & $\begin{array}{l}\stackrel{0}{0} \\
\dot{0}\end{array}$ & & $\stackrel{8}{\circ}$ & $\begin{array}{l}\stackrel{\leftrightarrow}{0} \\
\dot{0}\end{array}$ & & $\begin{array}{l}\stackrel{0}{0} \\
\stackrel{0}{0}\end{array}$ & & $\begin{array}{l}\stackrel{8}{0} \\
\dot{0}\end{array}$ & & $\stackrel{?}{\stackrel{R}{0}}$ & $\stackrel{?}{\stackrel{+}{0}}$ \\
\hline & $0^{\theta}$ & $\begin{array}{l}8 \\
\stackrel{9}{-}\end{array}$ & $\underset{\text { ஸి }}{\stackrel{8}{8}}$ & $\begin{array}{l}\stackrel{8}{8} \\
\dot{\leftrightarrow}\end{array}$ & $\begin{array}{l}\stackrel{8}{8} \\
\stackrel{\square}{\rightleftharpoons}\end{array}$ & $\begin{array}{l}8 \\
\text { 숟 }\end{array}$ & 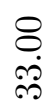 & $\begin{array}{l}8 \\
\stackrel{0}{0}\end{array}$ & $\begin{array}{l}8 \\
\qquad \dot{10} \\
\qquad\end{array}$ & $\begin{array}{l}8 \\
\dot{0}\end{array}$ & 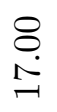 & $\begin{array}{l}8 \\
\infty \\
\infty \\
-1\end{array}$ & 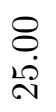 & 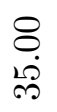 & $\begin{array}{l}8 \\
\stackrel{8}{0} \\
\stackrel{0}{-1}\end{array}$ & $\begin{array}{l}\stackrel{8}{8} \\
\stackrel{\leftrightarrow}{\text {. }}\end{array}$ & $\begin{array}{l}\stackrel{8}{8} \\
\stackrel{\square}{二}\end{array}$ & $\begin{array}{l}\stackrel{8}{8} \\
\infty \\
\stackrel{\sim}{N}\end{array}$ & $\begin{array}{l}8 \\
\dot{\infty}\end{array}$ \\
\hline & $\underbrace{e}_{a}$ & $\stackrel{8}{\stackrel{8}{0}}$ & $\begin{array}{l}8 \\
0 \\
0\end{array}$ & $\begin{array}{l}8 \\
8 \\
\infty \\
\infty \\
1\end{array}$ & $\begin{array}{l}8 \\
\stackrel{\infty}{\infty}\end{array}$ & $\underset{\text { 우 }}{8}$ & $\begin{array}{l}8 \\
\stackrel{8}{P} \\
\stackrel{p}{1}\end{array}$ & $\begin{array}{l}\stackrel{8}{8} \\
\stackrel{i}{ } \\
\text { I }\end{array}$ & $\begin{array}{l}8 \\
\dot{0} \\
\infty \\
\infty \\
1\end{array}$ & 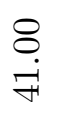 & $\begin{array}{l}\stackrel{8}{0} \\
\stackrel{\text { N }}{ }\end{array}$ & $\begin{array}{l}8 \\
\text { ô } \\
\text { i⿱ }\end{array}$ & $\begin{array}{l}8 \\
\stackrel{8}{0}\end{array}$ & $\begin{array}{l}8 \\
\stackrel{8}{+} \\
\underset{f}{1}\end{array}$ & 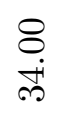 & $\underset{\text { ㅇ }}{8}$ & 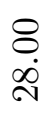 & $\begin{array}{l}8 \\
\stackrel{8}{0} \\
\stackrel{+}{+}\end{array}$ & $\begin{array}{l}\stackrel{8}{8} \\
\stackrel{1}{10}\end{array}$ \\
\hline \multirow{5}{*}{ 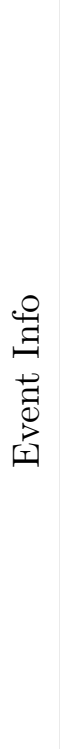 } & $\underset{\theta}{\stackrel{e}{e}}$ & $\stackrel{+!}{\stackrel{+}{\circ}}$ & $\begin{array}{l}0 \\
\stackrel{0}{\vec{m}} \\
\stackrel{m}{\rightarrow}\end{array}$ & 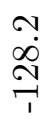 & 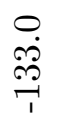 & $\stackrel{\rightrightarrows}{\stackrel{H}{*}}$ & 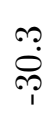 & 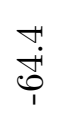 & $\begin{array}{l}\stackrel{10}{\stackrel{2}{0}} \\
\stackrel{8}{7}\end{array}$ & $\begin{array}{l}0 \\
\infty \\
\infty \\
\stackrel{0}{1} \\
T_{1}\end{array}$ & 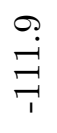 & $\begin{array}{l}\infty \\
\infty \\
\infty \\
\infty\end{array}$ & 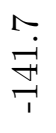 & 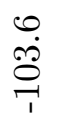 & 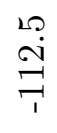 & $\underset{1}{\stackrel{10}{+}}$ & $\begin{array}{l}\stackrel{\not H}{0} \\
\underset{1}{7}\end{array}$ & $\stackrel{\sim}{\dot{S}}$ & $\begin{array}{l}\infty \\
\stackrel{\infty}{0} \\
\stackrel{1}{0}\end{array}$ \\
\hline & 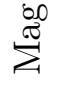 & $\begin{array}{l}\infty \\
0\end{array}$ & ִָ & مُ & $\ddot{0}$ & $\stackrel{\infty}{0}^{\infty}$ & $\underset{0}{0}$ & $\ddot{0}$ & סִ & 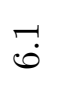 & $\begin{array}{l}0 \\
\dot{0}\end{array}$ & $\begin{array}{l}10 \\
0 \\
0\end{array}$ & $\stackrel{H}{\sim}$ & $\begin{array}{l}0 \\
0\end{array}$ & $\underset{0}{0}$ & $\underset{0}{0}$ & $\stackrel{?}{\sim}$ & $\begin{array}{l}0 \\
\dot{0}\end{array}$ & $\overparen{0}$ \\
\hline & 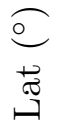 & $\begin{array}{l}\stackrel{8}{0} \\
\underset{+}{+} \\
+1\end{array}$ & $\begin{array}{l}\text { के } \\
\stackrel{\text { S }}{+}\end{array}$ & $\begin{array}{l}\infty \\
\infty \\
10 \\
\stackrel{1}{+}\end{array}$ & 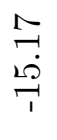 & 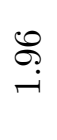 & $\begin{array}{l}\stackrel{\curvearrowright}{\sim} \\
\infty \\
\infty \\
\sim\end{array}$ & $\begin{array}{l}\infty \\
\stackrel{\infty}{\infty} \\
\sigma\end{array}$ & $\underset{\overbrace{}}{\stackrel{N}{\sim}}$ & $\begin{array}{l}0 \\
\dot{\varphi} \\
1\end{array}$ & $\begin{array}{l}\overline{20} \\
0 \\
0\end{array}$ & $\begin{array}{l}\stackrel{\leftrightarrow}{\infty} \\
\stackrel{\leftrightarrow}{\sim}\end{array}$ & $\begin{array}{l}\stackrel{g}{0} \\
\stackrel{\rho}{+}\end{array}$ & $\begin{array}{l}\stackrel{F}{f} \\
\stackrel{P}{P}\end{array}$ & $\begin{array}{l}\mathscr{8} \\
\stackrel{0}{\varphi}\end{array}$ & 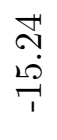 & 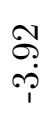 & $\begin{array}{l}\text { Nै } \\
\stackrel{p}{i}\end{array}$ & $\begin{array}{l}\overrightarrow{0} \\
\dot{\varphi}\end{array}$ \\
\hline & 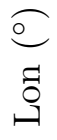 & $\begin{array}{l}10 \\
10 \\
\end{array}$ & $\begin{array}{l}0 \\
8 \\
10 \\
10 \\
7\end{array}$ & $\begin{array}{l}8 \\
0 \\
\infty \\
1 \\
T\end{array}$ & 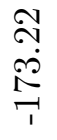 & $\begin{array}{l}\infty \\
2 \\
\dot{\rho} \\
\stackrel{\sim}{\sim} \\
\sim\end{array}$ & $\begin{array}{l}\not{D} \\
\infty \\
\infty \\
\infty\end{array}$ & 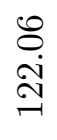 & 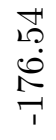 & & $\begin{array}{l}0 \\
\stackrel{1}{1} \\
\stackrel{10}{10}\end{array}$ & 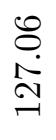 & 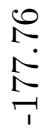 & $\begin{array}{l}\stackrel{N}{N} \\
\stackrel{0}{\oplus} \\
\stackrel{1}{+}\end{array}$ & $\begin{array}{l}8 \\
8 \\
10 \\
10\end{array}$ & 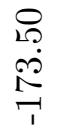 & $\begin{array}{l}\text { Oै } \\
\text { ô } \\
\text { i⿱ }\end{array}$ & $\begin{array}{l}\stackrel{H}{10} \\
\stackrel{\leftrightarrow}{H} \\
\stackrel{H}{+}\end{array}$ & 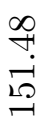 \\
\hline & $\begin{array}{l}\stackrel{0}{ \pm} \\
\stackrel{ \pm}{*}\end{array}$ & $\underset{\infty}{\stackrel{\vec{J}}{\rightleftharpoons}}$ & 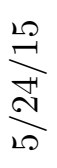 & $\underset{\not}{\stackrel{12}{=}}$ & $\frac{10}{\stackrel{D}{F}}$ & 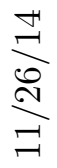 & 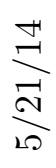 & $\underset{10}{\stackrel{+10}{=1}}$ & 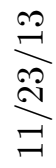 & $\begin{array}{l}\stackrel{10}{=} \\
\frac{1}{-1} \\
\sigma\end{array}$ & $\underset{\underset{N}{N}}{\stackrel{+}{=}}$ & 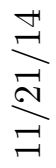 & $\underset{F}{\stackrel{\vec{f}}{\rightleftharpoons}}$ & $\frac{\stackrel{H}{\vec{N}}}{\frac{\stackrel{N}{N}}{N}}$ & $\frac{\vec{E}}{\stackrel{D}{-}}$ & $\stackrel{\stackrel{\infty}{\rightleftharpoons}}{\stackrel{\infty}{-}}$ & $\frac{\stackrel{\infty}{\rightleftharpoons}}{N}$ & $\stackrel{\stackrel{m}{=}}{\stackrel{\infty}{=}}$ & $\begin{array}{l}\stackrel{20}{=} \\
\frac{1}{=} \\
\sigma\end{array}$ \\
\hline & 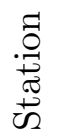 & $\begin{array}{l}\sum_{0} \\
\infty \\
\infty\end{array}$ & & & & 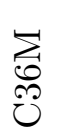 & & & & & & & & 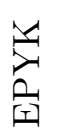 & & & & & \\
\hline
\end{tabular}




\begin{tabular}{|c|c|c|c|}
\hline & 1080 & & \\
\hline$\frac{a}{2}$ & 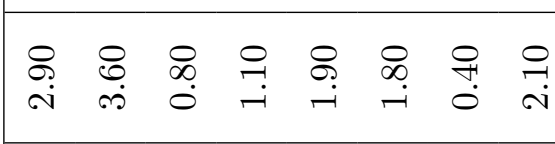 & 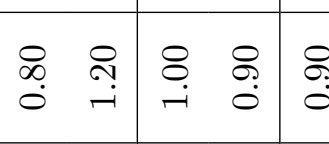 & 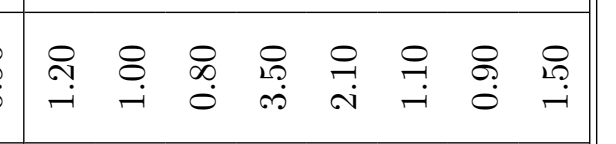 \\
\hline$:$ & 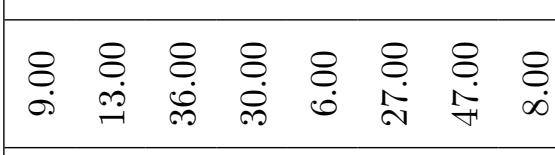 & 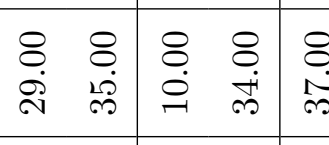 & 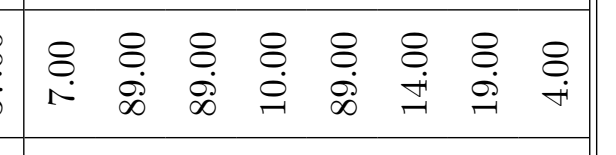 \\
\hline : & 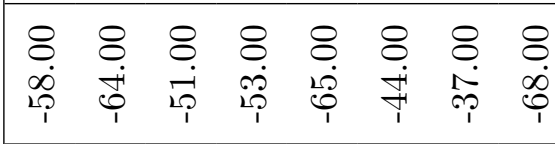 & 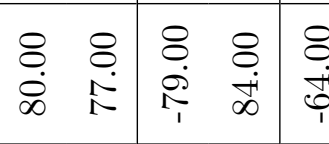 & 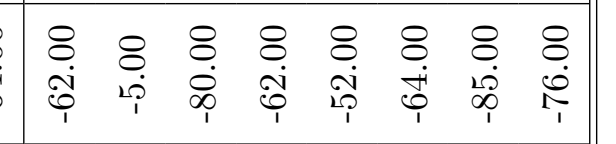 \\
\hline$\overline{\tilde{z}}$ & 8 & 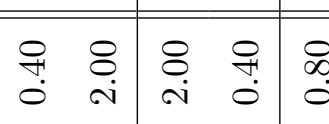 & 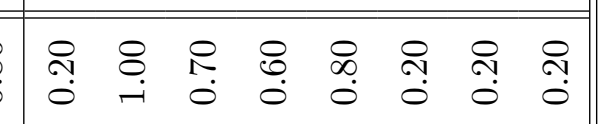 \\
\hline & 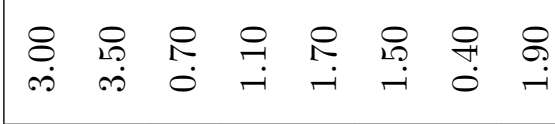 & 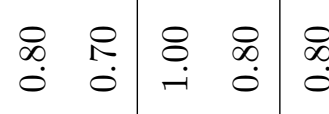 & 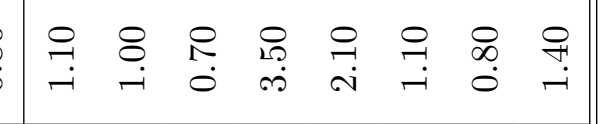 \\
\hline & 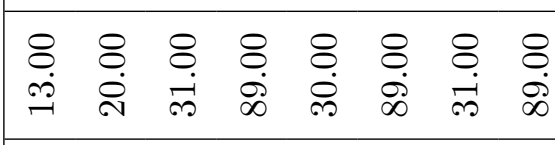 & 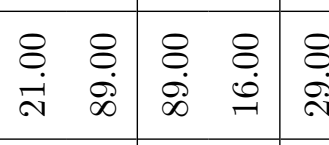 & 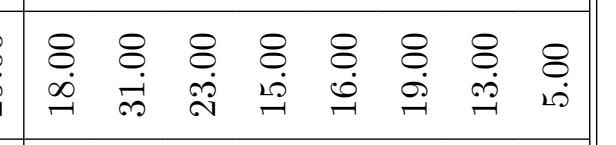 \\
\hline : & 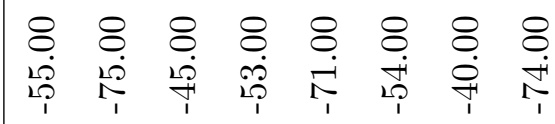 & 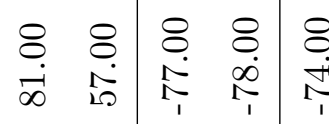 & 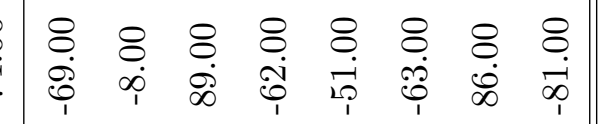 \\
\hline 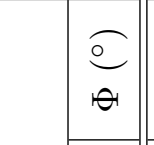 & 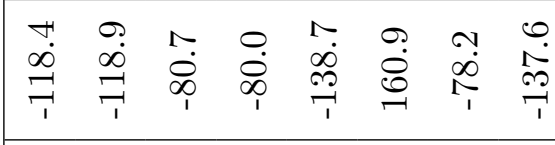 & 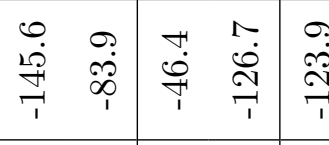 & 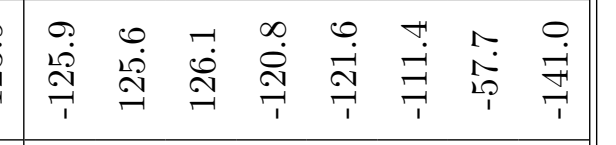 \\
\hline 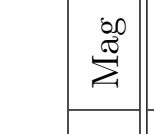 & 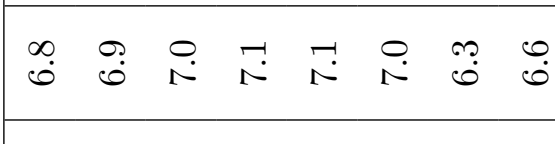 & $8: 8=8$ & 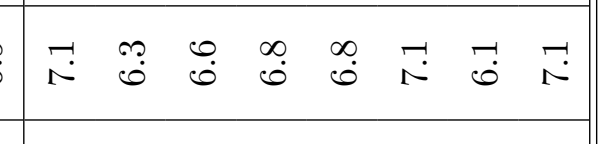 \\
\hline 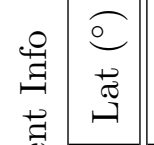 & 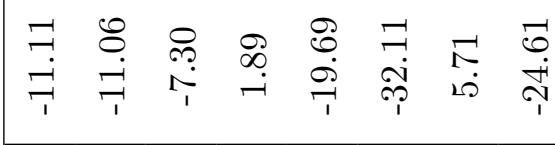 & 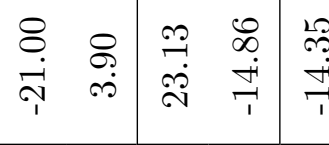 & 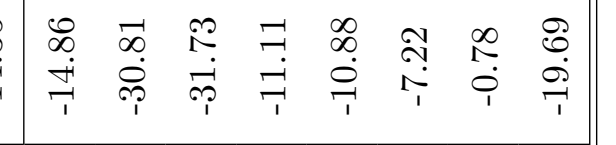 \\
\hline & 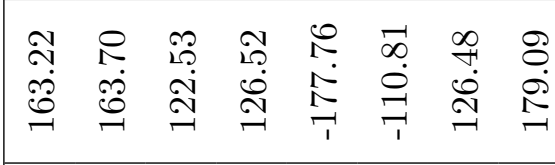 & 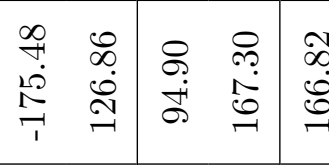 & 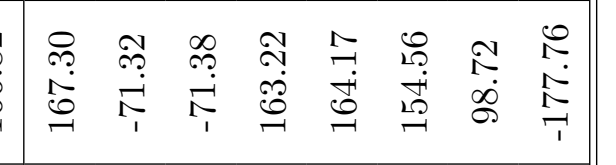 \\
\hline & 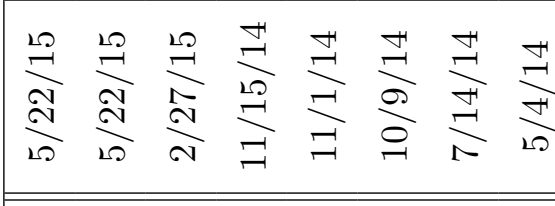 & & 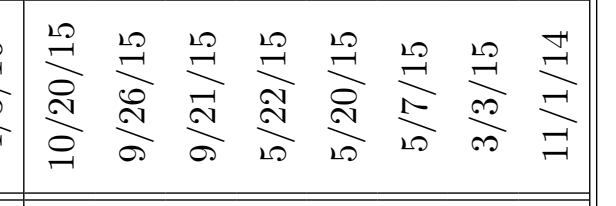 \\
\hline & & 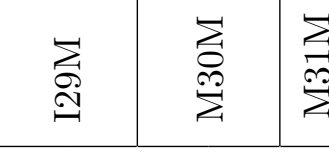 & 㪯 \\
\hline
\end{tabular}




\begin{tabular}{|c|c|c|}
\hline \multirow{2}{*}{\multicolumn{3}{|c|}{ 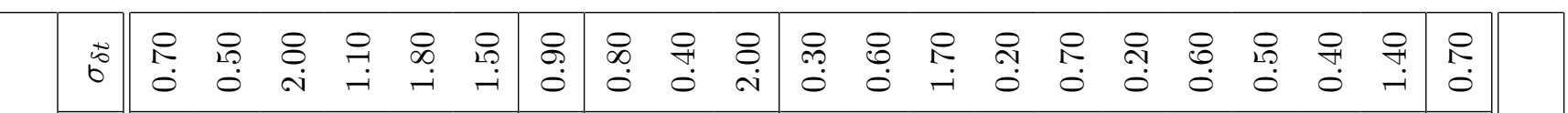 }} \\
\hline & & \\
\hline & 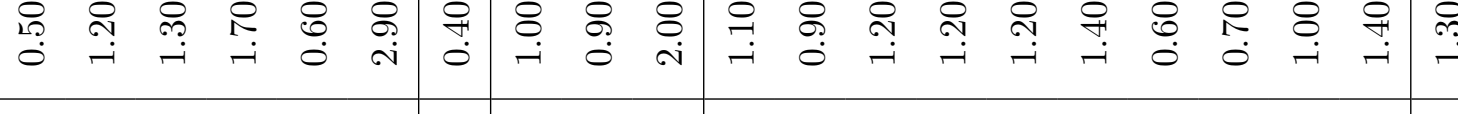 & \\
\hline & 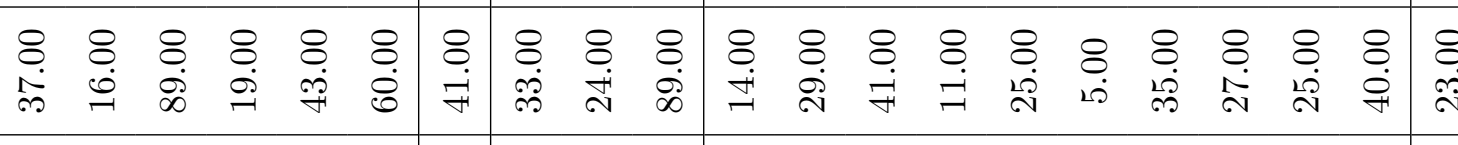 & \\
\hline & 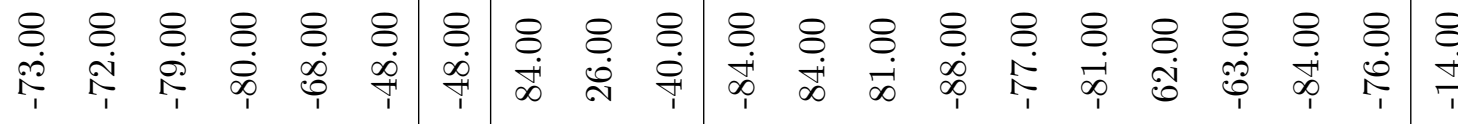 & \\
\hline 今 & 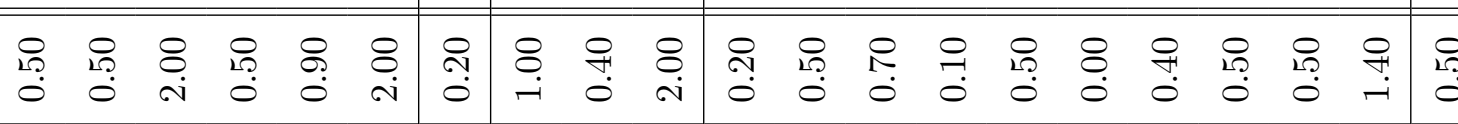 & \\
\hline & 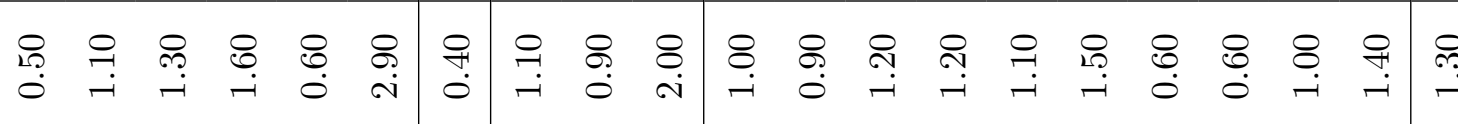 & \\
\hline & 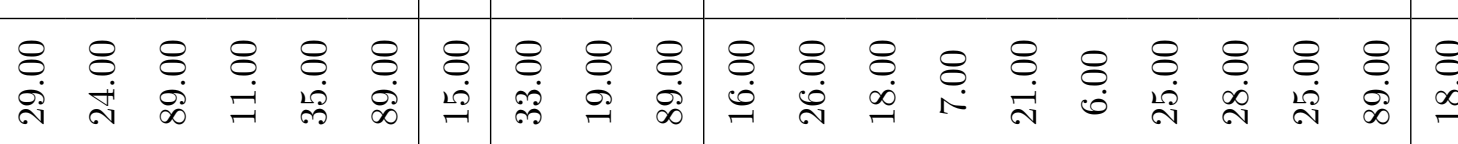 & \\
\hline & 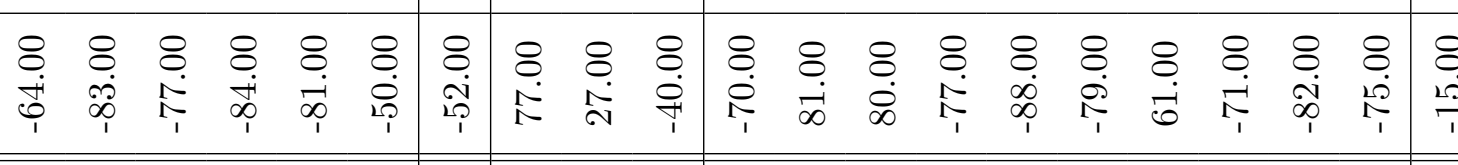 & \\
\hline & 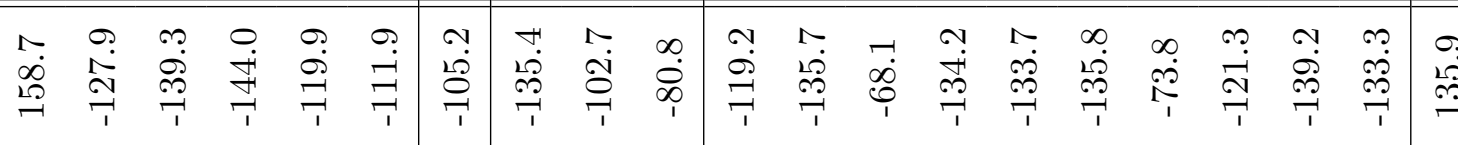 & \\
\hline & 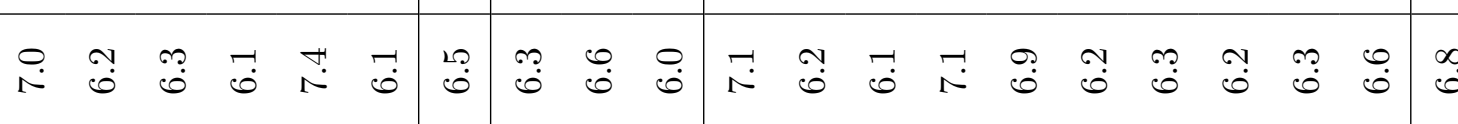 & \\
\hline & 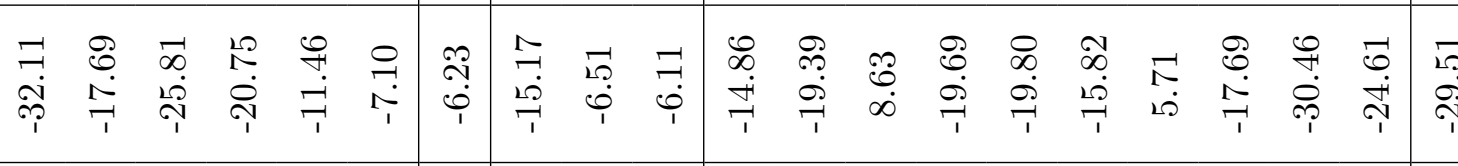 & \\
\hline & 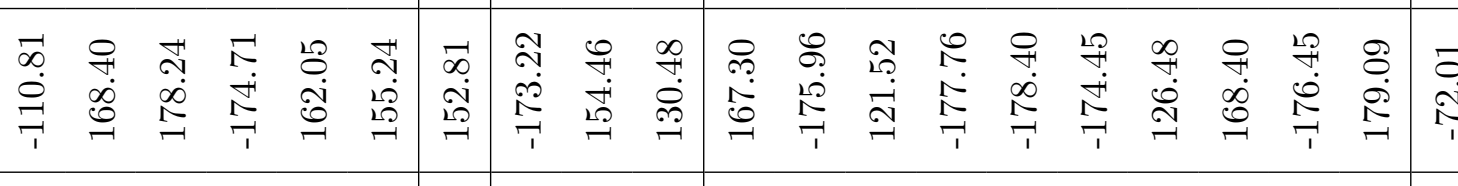 & \\
\hline & 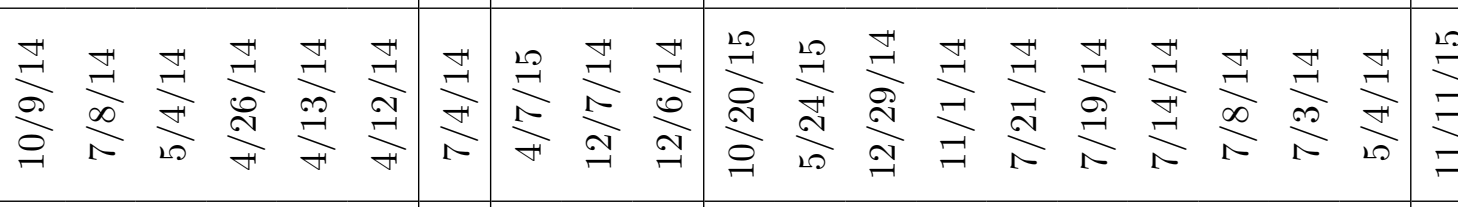 & \\
\hline & 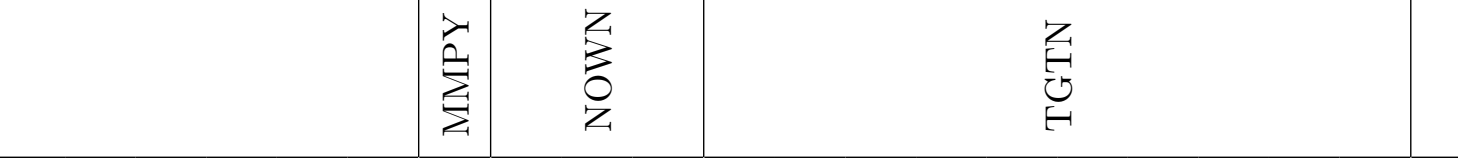 & \\
\hline
\end{tabular}




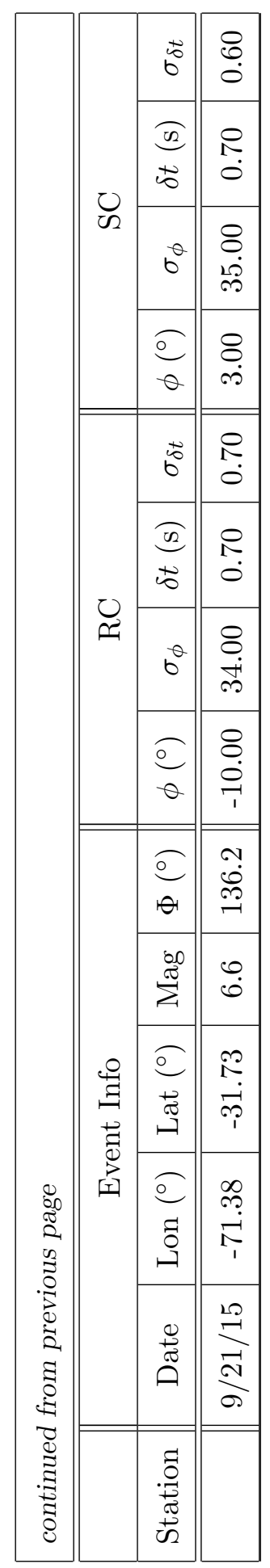

